\title{
Insect Management for Leafy Vegetables (Lettuce, Endive and Escarole) ${ }^{1}$
}

\section{G. S. Nuessly and S. E. Webb²}

Damage to leafy vegetables results from holes chewed in leaves by caterpillars and beetles, leaf mining by fly larvae and disease transmission and head contamination by piercing sucking insects. Major pests of these crops are beet and southern armyworms, cutworms, cabbage loopers, dipterous leafminers, aphids, cucumber beetles and wireworms. Less common pests of leafy vegetables include seedcorn maggot, seedcorn beetle and corn earworm.

\section{Beet Armyworm, Spodoptera exigua (Hubner)}

\section{Description}

Adult moths (Figure 1) have a wing span of $11 / 4$ in. Fore wings are brownish-gray with fine light and dark markings. The round spot in the middle of the wing (orbicular spot) is cream colored or has an orange center. Hind wings are light colored with a dark band near margin. Moths produce a mass of up to 100 eggs covered with scales. Newly emerged larvae are light with dark heads. As they mature over the 2-week larval stage, they become light to dark green with a light and dark stripe above the spiracles and another light stripe below the spiracles running the length of the caterpillar (Figure 2). There is usually a dark spot above these lines on the second thoracic segment. Suture on the front of the head form an inverted "Y." Larva have three pairs of true legs and five pairs of prolegs. The dark brown, $3 / 4$ to $1 \mathrm{in.} \mathrm{long} \mathrm{pupae} \mathrm{are} \mathrm{found} \mathrm{in} \mathrm{soil.}$

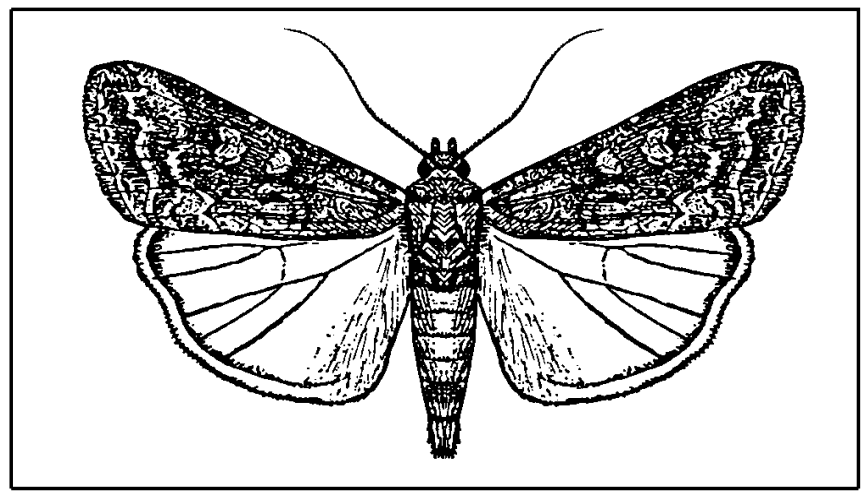

Figure 1. Beet armyworm adult.

1. This document is ENY-475 (which replaces ENY-430, ENY-432, and ENY-440), one of a series of the Entomology \& Nematology Department, Florida Cooperative Extension Service, Institute of Food and Agricultural Sciences, University of Florida. Published: July 2002. Revised: September 2005. For more publications related to horticulture/agriculture, please visit the EDIS Website at http://edis.ifas.ufl.edu/.

2. G. S. Nuessly, Associate Professor, Crop Protection, Everglades REC, Belle Glade and S. E. Webb, Associate Professor, Entomology and Nematology Department, Cooperative Extension Service, Institute of Food and Agricultural Sciences, University of Florida, Gainesville, 32611-0640.

The use of trade names in this publication is solely for the purpose of providing specific information. UF/IFAS does not guarantee or warranty the products named, and references to them in this publication does not signify our approval to the exclusion of other products of suitable composition. All chemicals should be used in accordance with directions on the manufacturer's label. Use pesticides safely. Read and follow directions on the manufacturer's label. 


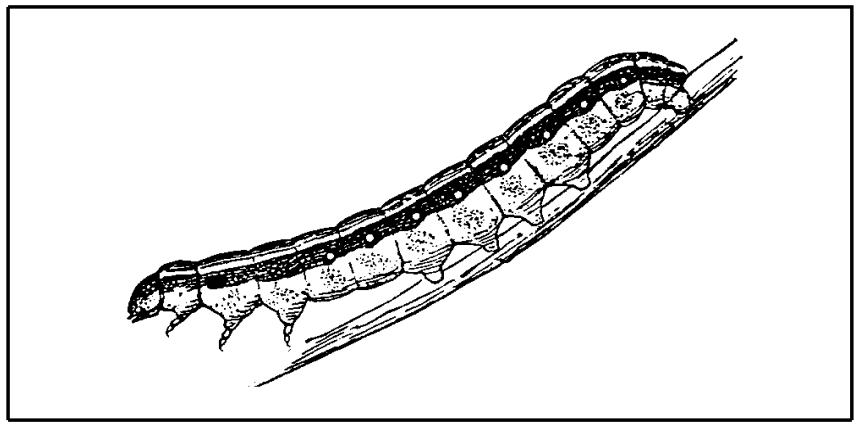

Figure 2. Beet armyworm larva.

\section{Biology}

Adults feed on nectar and other moisture sources. Larvae emerge from egg masses in 3 to 4 days. They feed in groups during their first instar and then disperse on the wind using silken threads. Larvae usually feed on the older leaves and move down into the crowns and into heads near the base of the plants. Larvae enter the soil to pupate after 2 to 2.5 week feeding. Adults emerge in 7 to 10 days.

\section{Damage}

These worms feed in the crown of the plant and can severely stunt or kill seedlings. The potential for damage is reduced between thinning and head formation. Beet armyworms may cause serious damage by boring in from the bottom of the head after lettuce head formation.
Table 1. Beet armyworm

\begin{tabular}{|c|c|}
\hline $\begin{array}{c}\text { Management } \\
\text { Options }\end{array}$ & Recommendation \\
\hline $\begin{array}{l}\text { Scouting/ } \\
\text { Thresholds }\end{array}$ & $\begin{array}{l}\text { Fields should be monitored at least } \\
\text { weekly for damage by caterpillars } \\
\text { feeding on leaves. Pheromone } \\
\text { traps can be used to monitor } \\
\text { relative presence of the adults in the } \\
\text { area. Young plants are more } \\
\text { susceptible to leaf feeding than } \\
\text { middle age plants before cupping } \\
\text { and head formation. Damage by } \\
\text { older larvae is often not visible } \\
\text { without pulling leaves apart to } \\
\text { further examine the crown. Look for } \\
\text { egg masses on the leaves. Look } \\
\text { toward the base of leaves for } \\
\text { damage and under outer leaves } \\
\text { near the soil surface for larvae that } \\
\text { may hide during the day away from } \\
\text { their feeding site. Treat if you find } \\
\text { one second or third instar larva per } \\
10 \text { plants from germination to } \\
\text { heading. After head formation, treat } \\
\text { if average count is }>1 \text { per } 25 \text { plants. } \\
\text { Best time to treat for this pest is in } \\
\text { early morning or early evening. }\end{array}$ \\
\hline Notes & $\begin{array}{l}\text { Insecticides are most effective } \\
\text { against the younger instars with } \\
\text { higher rates and more frequent } \\
\text { applications needed to try to control } \\
\text { later instars. Insecticides are } \\
\text { available for foliar applications. } \\
\text { Coverage and penetration are } \\
\text { important in treating for all of the } \\
\text { moth species. Use of surfactants to } \\
\text { increase head penetration and } \\
\text { surface coverage increase } \\
\text { insecticidal control. }\end{array}$ \\
\hline $\begin{array}{l}\text { Natural } \\
\text { Enemies }\end{array}$ & $\begin{array}{l}\text { Insect predators and parasitoids, as } \\
\text { well as pathogens aid in armyworm } \\
\text { control, but generally do not exert } \\
\text { enough pressure to prevent yield } \\
\text { loss. }\end{array}$ \\
\hline $\begin{array}{l}\text { Cultural } \\
\text { Controls }\end{array}$ & $\begin{array}{l}\text { Field disking and destruction of crop } \\
\text { residues are important for control of } \\
\text { all caterpillar, aphid and leafminer } \\
\text { pests of leafy vegetables to reduce } \\
\text { their migration into nearby crops. } \\
\text { Beet armyworms develop well on } \\
\text { several weeds in the Amaranth } \\
\text { group, so weed control on ditch } \\
\text { banks surrounding fields can help } \\
\text { reduce populations before they } \\
\text { invade fields. }\end{array}$ \\
\hline
\end{tabular}




\section{Southern Armyworm, Spodoptera eridania (Cramer)}

\section{Description}

Adult moths (Figure 3 ) have a wingspan of 1 1/2 in. The fore wings are streaked with cream, gray, light brown, and black, and have an elongate white mark across the rear outer corner. A dark kidney-shaped spot (reniform spot) is present near the middle of the fore wings. Hind wings are white with a few dark marks on the margins. Females produce large egg masses of 100 to 200 eggs covered with scales from their abdomens. Eggs are usually deposited on the undersides of leaves. The larvae are often very colorful and grow to $2 \mathrm{in}$. long at maturity (Figure 4). Head color is light to reddish-brown. Their bodies have a narrow, almost continuous white to orange stripe down the center of the back. A yellowish to orange broad band runs backward from the first abdominal segment below the spiracles. Some to all abdominal and some thoracic segments have dark triangular markings near the center of the back. Darker specimens exist where bands and markings are very faint. Each thoracic segment and first two abdominal segments are larger than previous segment giving a distinctive swollen or hump-backed appearance to larvae, particularly in late instars. Sutures on front of head form an inverted "Y." Larvae have three pairs of true legs and five pairs of prolegs. Brown 3/4 to 1 in long pupae are found in the soil.

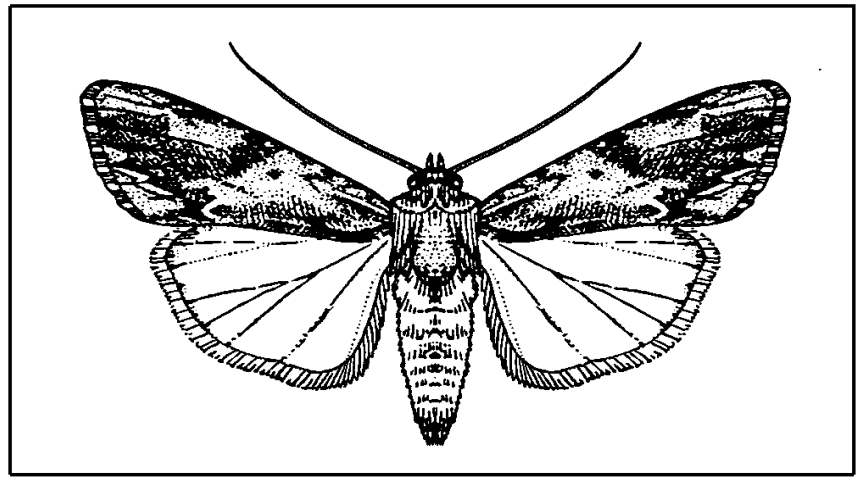

Figure 3. Southern armyworm adult.

\section{Biology}

Adults feed on nectar and other moisture sources. Larvae emerge from egg masses in 3 to 4 days. They feed in groups during their first instar and then

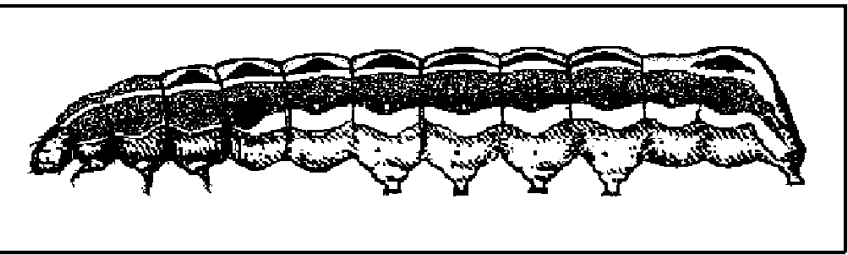

Figure 4. Southern armyworm larva.

disperse on the wind using silken threads. All age larvae feed near leaf edges and may move down into the crowns and into heads near the base of the plants as they get older. Larvae enter the soil to pupate after 2 to 3 weeks feeding. Adults emerge from soil in 7 to 8 days.

Table 2. Southern armyworm

\begin{tabular}{|c|c|}
\hline $\begin{array}{c}\text { Management } \\
\text { Options }\end{array}$ & Recommendation \\
\hline $\begin{array}{l}\text { Scouting/ } \\
\text { Thresholds }\end{array}$ & $\begin{array}{l}\text { Fields should be monitored at least } \\
\text { weekly for damage by caterpillars } \\
\text { feeding on leaves. Pheromone } \\
\text { traps can be used to monitor } \\
\text { occurrence of moths. Young plants } \\
\text { are more susceptible to leaf } \\
\text { feeding than middle age plants } \\
\text { before cupping and head } \\
\text { formation. Look for egg masses on } \\
\text { the leaves. The dark bodied larvae } \\
\text { are usually visible feeding on the } \\
\text { leaves. Treat if you find one } \\
\text { second or third instar larva per } 10 \\
\text { plants from germination to } \\
\text { heading. After head formation, } \\
\text { treat if average count is }>1 \text { per } 25 \\
\text { plants. Best time to treat for this } \\
\text { pest is in early morning or early } \\
\text { evening. }\end{array}$ \\
\hline Notes & $\begin{array}{l}\text { Insecticides are most effective } \\
\text { against the younger instars with } \\
\text { higher rates and more frequent } \\
\text { applications needed to try to } \\
\text { control later instars. Insecticides } \\
\text { are available for foliar applications. } \\
\text { Coverage and penetration are } \\
\text { important in treating for all of the } \\
\text { moth species. Use of surfactants to } \\
\text { increase head penetration and } \\
\text { surface coverage increase } \\
\text { insecticidal control. }\end{array}$ \\
\hline $\begin{array}{l}\text { Natural } \\
\text { Enemies }\end{array}$ & $\begin{array}{l}\text { Insect predators and parasitoids, } \\
\text { as well as pathogens aid in } \\
\text { earworm control, but generally do } \\
\text { not exert enough pressure to } \\
\text { prevent yield loss. }\end{array}$ \\
\hline
\end{tabular}


Table 2. Southern armyworm

\begin{tabular}{||l|l||}
\hline \hline \begin{tabular}{|l} 
Management \\
Options
\end{tabular} & \multicolumn{1}{|c||}{ Recommendation } \\
\hline $\begin{array}{l}\text { Cultural } \\
\text { Controls }\end{array}$ & $\begin{array}{l}\text { Field disking and destruction of } \\
\text { crop residues are important for } \\
\text { control of all caterpillar, aphid and } \\
\text { leafminer pests of leafy vegetables } \\
\text { to reduce their migration into } \\
\text { nearby crops. Southern } \\
\text { armyworms develop well on } \\
\text { several weeds in the Amaranth } \\
\text { group, so weed control on ditch } \\
\text { banks surrounding fields can help } \\
\text { reduce populations before they } \\
\text { invade fields. }\end{array}$ \\
\hline
\end{tabular}

\section{Cabbage Looper, Trichoplisia ni (Hubner)}

\section{Description}

The forewings ( $11 / 2$ in. wingspan) of the cabbage looper moth (Figure 5) are dark grayish brown with connected silvery markings that resemble a figure eight. Their hind wings are light brown at the base and become progressively darker toward the wing margins. Eggs are roundish with a flat bottom, yellowish white to greenish and are marked by ridges running down the sides from the top. Young cabbage loopers (Figure 6) are dirty white and become light to medium green. Their skin is smooth with numerous short hairs that become less dense as the larvae advance through five instars. They are marked with a narrow, white stripe along each side above the spiracles and several fine lines running down the center of the back. The body gradually increases in size from the narrow head end to a broader end of the abdomen. Looper larvae walk with the characteristic "inch worm" looping or arching of their bodies along the plant surface. This is facilitated by the arrangement of 3 pairs of true legs and only three pairs of prolegs. Larvae spin a thin white cocoon under leaves or other protected locations in which they pupate. The 3/4 to $1 \mathrm{in}$. long pupae are initially green, but become dark as the adult develops within.

\section{Biology}

Adults feed on nectar and other moisture sources. Eggs are deposited usually under leaves singly or in small groups of up to seven. Females can produce

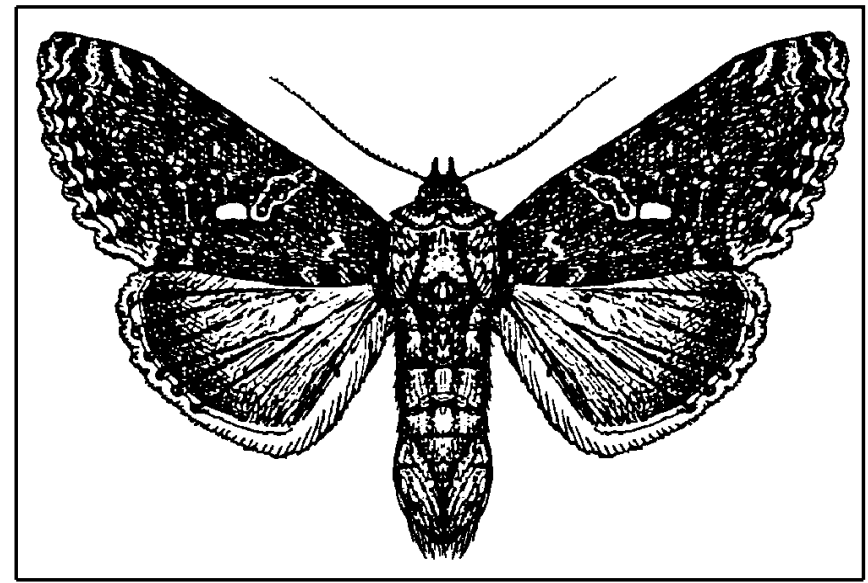

Figure 5. Cabbage looper adult male.

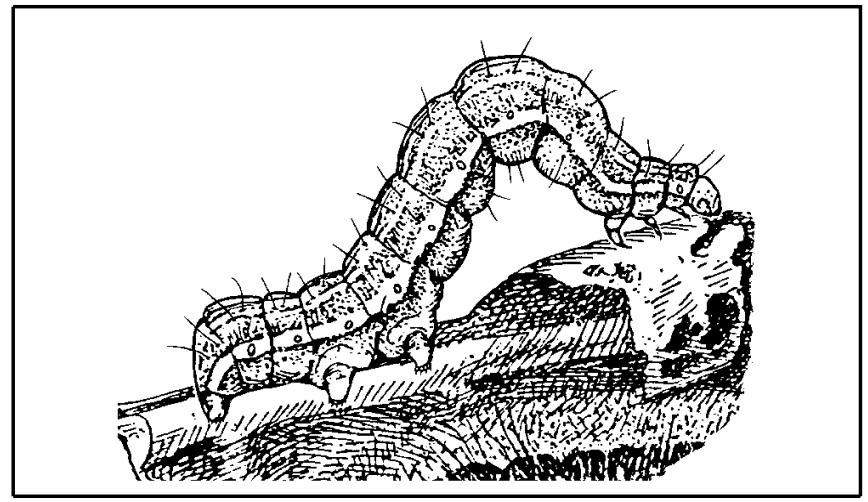

Figure 6. Cabbage looper larva.

300 to 600 eggs during their two week life span. Larvae emerge from eggs in 3 to 4 days to feed on leaves. Larvae feed and develop for 2 to 4 weeks, reaching a length of about 1-1/2 inches. They spin cocoons on the host plant within which they pupate. Adults emerge from pupae in 5 to 10 days.

\section{Damage}

The cabbage looper feeds on a variety of crops and is one of the most destructive insect pests of vegetables. Young larvae feed on the lower surface of outer leaves leaving a windowpane of the upper leaf surface. Older larvae feed through the leaves leaving large holes that frequently penetrate into the heads. Although seedlings are occasionally damaged, most injury occurs after heading. Young plants between seedling stage and heading can tolerate substantial leaf damage without loss of yield. 
Table 3. Cabbage looper

\begin{tabular}{|c|c|}
\hline $\begin{array}{c}\text { Management } \\
\text { Options }\end{array}$ & Recommendation \\
\hline $\begin{array}{l}\text { Scouting/ } \\
\text { Thresholds }\end{array}$ & $\begin{array}{l}\text { Look for holes in leaves and lots of } \\
\text { sticky, green to light brown fecal } \\
\text { material near feeding holes. Black } \\
\text { lights and pheromone traps can be } \\
\text { used to monitor for presence of } \\
\text { adults. Threshold levels used in } \\
\text { cabbage call for insecticide } \\
\text { treatment just prior to heading } \\
\text { when populations reach }>1 \text { per } 25 \\
\text { plants. }\end{array}$ \\
\hline Notes & $\begin{array}{l}\text { Insecticides are available for foliar } \\
\text { applications. Cabbage looper } \\
\text { populations have increased in } \\
\text { recent years, perhaps in response } \\
\text { to reduction in the use of } \\
\text { pyrethroid insecticides. The newer } \\
\text { chemical and biological } \\
\text { insecticides used for other } \\
\text { immature moth species are also } \\
\text { effective against cabbage loopers. } \\
\text { Coverage and penetration are } \\
\text { important in treating for all of the } \\
\text { moth species. Use of surfactants to } \\
\text { increase head penetration and } \\
\text { surface coverage increase } \\
\text { insecticidal control. }\end{array}$ \\
\hline $\begin{array}{l}\text { Natural } \\
\text { Enemies }\end{array}$ & $\begin{array}{l}\text { Looper larvae and pupae are } \\
\text { attacked by a large number of } \\
\text { insect predators and parasitoids, } \\
\text { as well as bacterial and viral } \\
\text { pathogens. However, in } \\
\text { commercial settings these natural } \\
\text { enemies may not respond quickly } \\
\text { enough to prevent economic } \\
\text { injury. }\end{array}$ \\
\hline $\begin{array}{l}\text { Cultural } \\
\text { Controls }\end{array}$ & $\begin{array}{l}\text { Cabbage loopers prefer cole crops } \\
\text { to lettuce, but practices of planting } \\
\text { such crops between plantings of } \\
\text { lettuce increase the chance of } \\
\text { damage by this pest. }\end{array}$ \\
\hline
\end{tabular}

\section{Corn Earworm, Heliocoverpa zea}

\section{Description}

The front wing color in adults is sex dependent. Female fore wings are yellow to pinkish-brown, while those of males are light greenish-brown. There is usually a dark spot in the middle of the fore wing (reniform spot). Both fore and hind wings have dark margins. The hind wings have a short, narrow band near the middle with two pale spots near the edge of the wing in the dark margin. Both sexes have a wingspan of 1 1/2 in (Figure 7). The ball shaped, white to yellow to green eggs have visible ridges running from top to bottom. Newly emerged larvae are translucent white to yellow with a light brown head. Older larvae (Figure 8) vary considerably from dark yellow to green to tan to dark brown. Mature larvae can reach $2 \mathrm{in.}$ Larvae have three pairs of true legs and five pairs of prolegs. The skin (cuticle) of larvae are covered with microspines (need good hand lens or microscope to see microspines). The dark colored tubercles (larger bumps) on abdominal segments 1,2 and 8 do not have microspines more than $1 / 4$ the way to their apex. The central area on the inside surface of the mandibles does not have a separate toothed area. The 3/4 in. long pupae are reddish-brown in color.

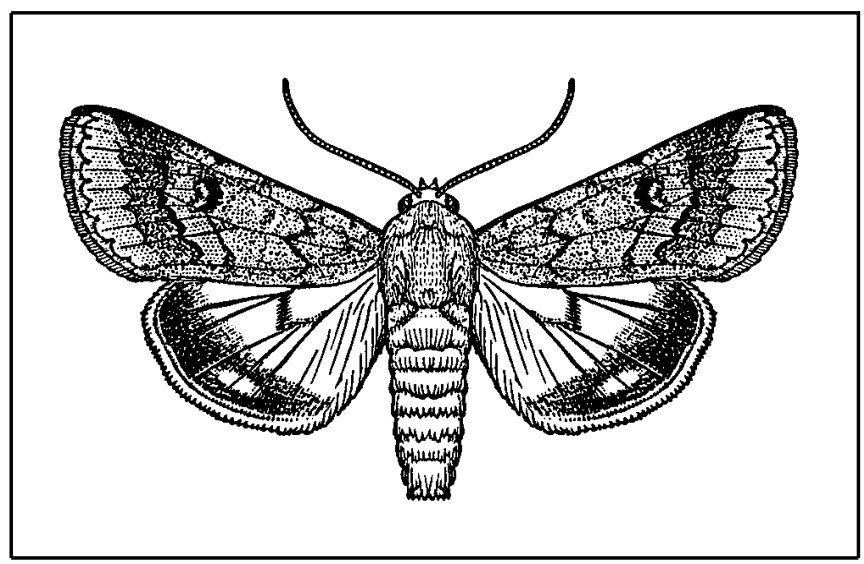

Figure 7. Corn earworm adult.

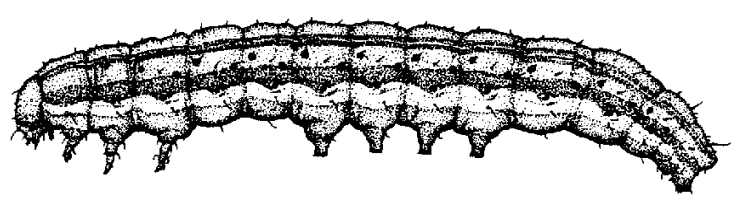

Figure 8. Corn earworm larva.

\section{Biology}

Corn earworm moths feed on nectar and other moisture sources. Females deposit their eggs singly or in small groups of less than five on leaves. The eggs are not protected by scales. Larvae emerge from eggs in 3 to 4 days to feed on leaves. Larvae leave plants to pupate within the soil. Adults emerge in 7 to 10 days. Corn earworms complete their development from egg to adult in 28 to 40 days. 


\section{Damage}

Young larvae feed on outer leaves before moving into the more protected inner leaves. Corn earworms can destroy lettuce seedlings by feeding on the crown. They also bore into heads of maturing lettuce where they are difficult to find and control.

Table 4. Corn earworm

\begin{tabular}{|c|c|}
\hline $\begin{array}{l}\text { Management } \\
\text { Options }\end{array}$ & Recommendation \\
\hline $\begin{array}{l}\text { Scouting/ } \\
\text { Thresholds }\end{array}$ & $\begin{array}{l}\text { Fields should be monitored at least } \\
\text { weekly for damage by caterpillars } \\
\text { feeding on leaves. Pheromone } \\
\text { traps can be used to monitor } \\
\text { occurrence of moths. Young plants } \\
\text { are more susceptible to leaf feeding } \\
\text { than middle age plants before } \\
\text { cupping and head formation. } \\
\text { Between thinning and heading, treat } \\
\text { if you find an average of more than } \\
\text { one larva for each two plants. } \\
\text { Further applications may be } \\
\text { necessary. Once heads form, treat } \\
\text { if you find an average of one larva } \\
\text { in every } 25 \text { plants. }\end{array}$ \\
\hline Notes & $\begin{array}{l}\text { Insecticides are most effective } \\
\text { against the younger instars with } \\
\text { higher rates and more frequent } \\
\text { applications needed to try to control } \\
\text { later instars. Insecticides are } \\
\text { available for foliar applications. } \\
\text { Coverage and penetration are } \\
\text { important in treating for all of the } \\
\text { moth species. Use of surfactants to } \\
\text { increase head penetration and } \\
\text { surface coverage increase } \\
\text { insecticidal control. }\end{array}$ \\
\hline $\begin{array}{l}\text { Natural } \\
\text { Enemies }\end{array}$ & $\begin{array}{l}\text { Insect predators and parasitoids, as } \\
\text { well as pathogens aid in earworm } \\
\text { control, but generally do not exert } \\
\text { enough pressure to prevent yield } \\
\text { loss. }\end{array}$ \\
\hline $\begin{array}{l}\text { Cultural } \\
\text { Controls }\end{array}$ & $\begin{array}{l}\text { Field disking and destruction of crop } \\
\text { residues are important for control of } \\
\text { all caterpillar, aphid and leafminer } \\
\text { pests of leafy vegetables to reduce } \\
\text { their migration into nearby crops. }\end{array}$ \\
\hline
\end{tabular}

\section{Cutworms}

\section{Description}

Cutworm adults are large bodied moths with various dark patterns over light to medium brown or gray base color of fore wings. Shapes and coloration of spots on front wings are diagnostic in the identification of adult cutworm species. The wing spans of both the black (Agrotis ipsilon (Hufnagel)) (Figure 9) and variegated (Peridroma saucia (Hubner)) cutworms (Figure 10) ranges from $15 / 8$ to $21 / 8$ in, while the wings of the granulate cutworm (Feltia subterranea $(\mathrm{F}$.$) ) (Figure 11) are slightly$ narrower at $11 / 4$ to $13 / 4$ in. Black cutworm moth coloration is different between the sexes. However, in both sexes the kidney-shaped (reniform) spot is a dark crescent-shaped ring with a dark line emanating outward and hind wings are whitish to gray with dark scales on veins. The claviform spot (proximal to and beneath reniform spot) is an elongate oval, and the orbicular spot (proximal to reniform spot) is small and round to tear-shaped. Wing color in granulate cutworms varies greatly. Both sexes are recognized by the black bar between the usually pale, basal, round (orbicular) and kidney-shaped (reniform) spots on the fore wings. Hind wings are off-white with veins and margins sometimes darker. There is less distinction between the sexes in wing coloration for variegated cutworms. The kidney-shaped reniform and nearly round orbicular spots in the central fore wing are both large and ringed with black. The rear half of the forewings are clay-colored with blackish spots. Hind wings are irridescent to pearly white with brown veins and margins.

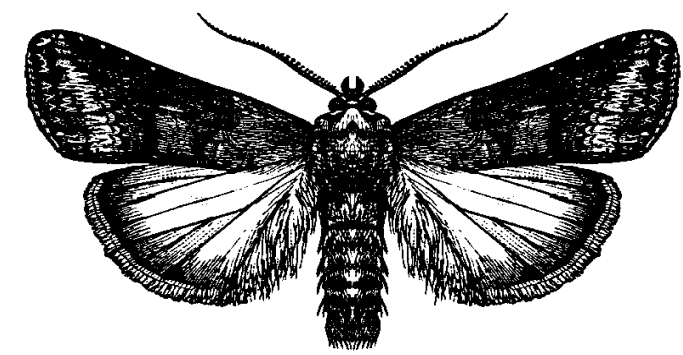

Figure 9. Black cutworm adult.

Eggs of all three species are whitish and become variegated brown with age and have ribs radiating 


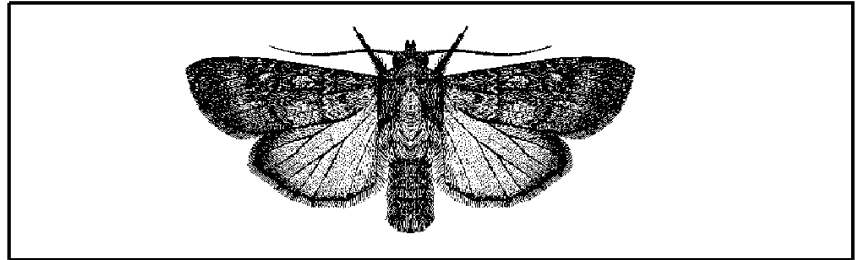

Figure 10. Variegated cutworm adult.

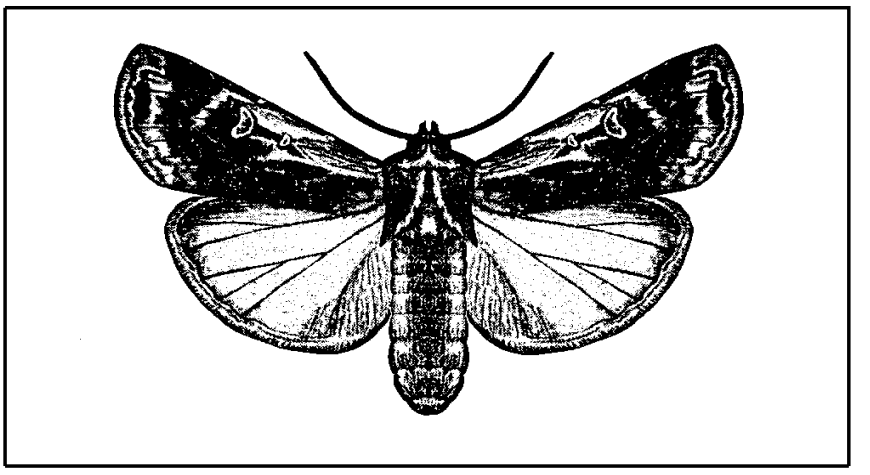

Figure 11. Granulate cutworm adult.

downward from the top. Black cutworms eggs are spherical shaped, those of granulate cutworms are rounded with flat bottoms and variegated cutworms eggs are rounded with rounded bottoms.

All cutworm larvae have sutures on the front of the head that form an inverted " $\mathrm{V}$ " and all have three pairs of true legs and five pairs of prolegs. Black cutworm larval (Figure 12) color ranges from light gray to black on top and lighter below. Two lighter stripes running down the center of the back are visible on lighter specimens, but all larvae lack an obvious band down their back. Two rows of small, black, raised bumps (tubercles) run down the back; two per segment. The cuticle is covered with large and small granules (need hand lens or microscope to see granules). Their heads are brownish with many dark spots. Granulate cutworm larvae (Figure 13) are gray to reddish brown with dull yellowish subdorsal markings on the abdominal segments. The heads are yellowish to brownish. The undersurface of the body is flecked with white. Granules on cuticle are isolated, blunt, and pointing slightly backward. Body color in variegated cutworms (Figure 14) is brownish gray to nearly black on top of back and lighter below. A row of whitish to yellow circular spots run down the center of the back, particularly on the first four abdominal segments. Cuticle is smooth without granulation. An orange to brown line may connect the spiracles, below which there is usually some yellowish to orangish coloration. The head is orange-brown and marked with darker spots. The pupae of all species are reddish brown to brown, 5/8 to $7 / 8$ in. long and are found in the soil.

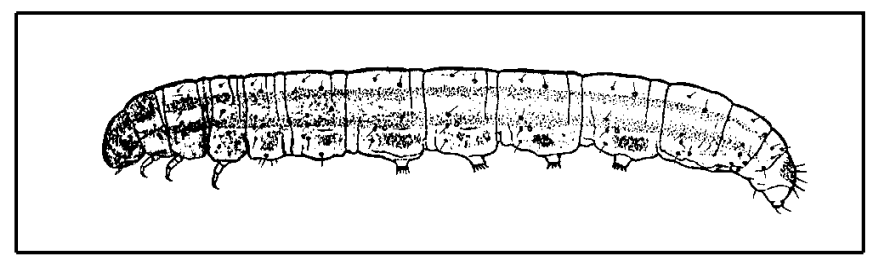

Figure 12. Black cutworm larva.

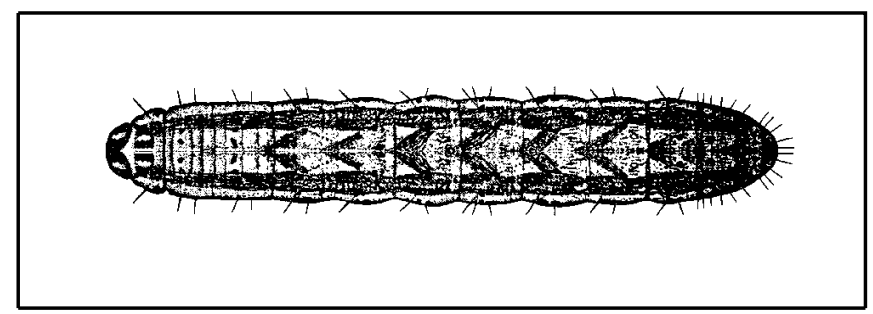

Figure 13. Granulate cutworm larva.

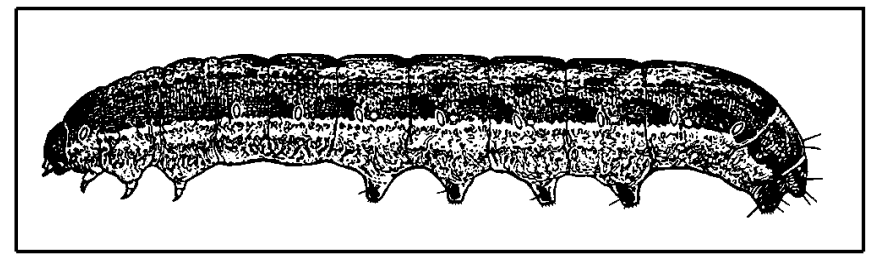

Figure 14. Variegated cutworm larva.

\section{Biology}

Cutworm moths feed on nectar and other moisture sources. Moths begin depositing eggs on field debris, stubble or leaves near the soil surface 7 to 10 days after emergence. Black cutworm eggs are deposited singly or in groups of up to 30 , granulate cutworms eggs are deposited singly or in small groups of $<5$ and variegated cutworms deposit masses of up to several hundred eggs. Larvae emerge from eggs in 3 to 6 days. They feed on leaves and stems of mostly young plants. Older larvae (4th instar and later) can reach 2 in. in length and can cut plants off at their bases and drag them to their burrow in soil. Larvae tend to curl up into a ring when disturbed or handled. They may also bite and release a greenish-brown fluid. Larvae complete development in 20 to 40 days. Larvae pupate within a chamber in the soil. Adults emerge in 10 to 20 days. Generation time for cutworms is 35 to 70 days, depending on temperature. 


\section{Damage}

Cutworms usually cut seedlings off at or just below the soil line. They may also bore into heads, and some species may damage leaves. All three of these cutworms are pests of most vegetables throughout Florida. Damage includes leaf feeding and stand loss due to cutting off entire plants. Black cutworms do most of their feeding at ground level. Larvae feed on young plants, cutting off leaves, or in later instars, entire plants. Populations of this pest tend to be higher in weedy and in wet fields.

Granulate cutworm larvae can cut off entire seedling plants, as well as climb and feed on leaves of older plants. This cutworm is not associated with weedy fields as is the black cutworm. First instar larvae stay on plants, while older larvae climb and feed on plants only during night. Variegated cutworm larvae cut off seedlings at ground level or defoliate older plants.

Table 5. Cutworms

\begin{tabular}{||l|l||}
\hline \multicolumn{1}{|c|}{$\begin{array}{c}\text { Management } \\
\text { Options }\end{array}$} & \multicolumn{1}{c|}{ Recommendation } \\
\hline Thresholds & $\begin{array}{l}\text { Seedling crops should be scouted as } \\
\text { frequently as twice per week to } \\
\text { detect cutworms or their damage, } \\
\text { particularly in areas known for } \\
\text { cutworms. Young larvae may be } \\
\text { found grouped together on foliage, } \\
\text { but older larvae will usually be found } \\
\text { in soil or beneath leaf trash during } \\
\text { the day. Look for wilted foliage or } \\
\text { plants with severed stems. Adults } \\
\text { can be monitored with black light and } \\
\text { pheromone traps. }\end{array}$ \\
\hline Notes & $\begin{array}{l}\text { Insecticides are available for } \\
\text { at-plant, pre- and post-emergence } \\
\text { broadcast and banded applications. } \\
\text { Post emergence applications are the } \\
\text { most efficient. }\end{array}$ \\
\hline Natural & $\begin{array}{l}\text { Natural enemies such as parasitic } \\
\text { wasps, flies and predacious ground } \\
\text { beetles can exert tremendous } \\
\text { control pressure that may approach } \\
80 \% \text { However, seedlings emerging } \\
\text { in fields without resident natural } \\
\text { enemy populations can experience } \\
\text { significant stand loss from first } \\
\text { generation cutworms. Larvae are } \\
\text { also targets for attack by pathogenic } \\
\text { fungi and viruses. }\end{array}$ \\
\hline \hline
\end{tabular}

Table 5. Cutworms

\begin{tabular}{||l|l||}
\hline \hline $\begin{array}{l}\text { Management } \\
\text { Options }\end{array}$ & \multicolumn{1}{c||}{ Recommendation } \\
\hline $\begin{array}{l}\text { Cultural } \\
\text { Controls }\end{array}$ & $\begin{array}{l}\text { Weedy fields quickly rotated to leafy } \\
\text { vegetables have higher potential for } \\
\text { stand loss due to surviving older } \\
\text { larvae cutting off the emerging } \\
\text { plants. Therefore, prepare fallowed } \\
\text { fields for production as soon as } \\
\text { possible to allow time for surviving } \\
\text { larvae to complete development } \\
\text { before planting leafy vegetable } \\
\text { crop. }\end{array}$ \\
\hline \hline
\end{tabular}

\section{Leafminers, Liriomyza trifolii Burgess}

\section{Description}

Adults (Figure 15) are small black to gray flies with yellow markings about $3 / 32$ in long. The minute eggs are transparent to creamy white. The larvae (maggots) are bright yellow to greenish yellow with a pair of retractable black mouth hooks. Larvae grow to about $1 / 8$ in long. Light redish pupae become dark brown as the adult develops within.

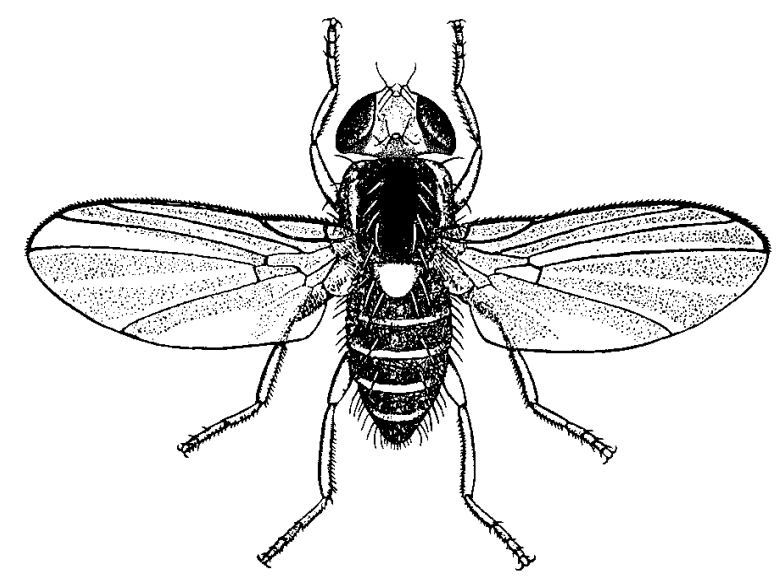

Figure 15. Vegetable leafminer adult.

\section{Biology}

Adults feed on nectar and other moisture sources as well as from fluids leaking from wounds in the leaf tissue made by the female with her ovipositor. They can live for 3 to 4 weeks with the females far outliving the males. Eggs are inserted singly into leaf tissue. Adults prefer to feed from younger leaves and 
to deposit eggs in older leaves. The fly feeds and develops on many vegetable crops and surrounding weeds. Larvae emerge from eggs within the leaves after 2 to 4 days. Larvae feed between the upper and lower surface of the leaves, leaving tunnels that appear white or light green. Larvae are visible through the leaf epidermis. Dead larvae and the immature stages of their parasitoid natural enemies can also be seen within the mines. Leafminer larvae pass through three larval instars before cutting a slit in the leaf surface to facilitate their exit. Larvae make their way to the soil, leaf trash or to the base of live lettuce leaves to pupate within the cuticle of their last larval instar. Many generations occur each year and the entire life cycle can be completed in 2 to 3 weeks in south Florida.

\section{Damage}

The main damage is caused by larvae mining the leaves. This may result in reduced photosynthesis or reduced availability of photosynthate to the growing plant. Younger plants are more sensitive and can be killed by severe infestations. Older plants more readily tolerate attacks by this pest, however mining on the wrapper leaves can throw the heads out of grade, even though the damage is often merely cosmetic. Removing infested wrapper leaves takes time and reduces the size and weight of the head which ultimately results in higher head counts per crate or reduced crate weight. Therefore, field areas with dense infestations may be passed up at harvest.

Table 6. Leafminers

\begin{tabular}{||l|l||}
\hline \begin{tabular}{|} 
Management \\
Options
\end{tabular} & \multicolumn{1}{c|}{ Recommendation } \\
\hline $\begin{array}{l}\text { Scouting/ } \\
\text { Thresholds }\end{array}$ & $\begin{array}{l}\text { Scout seedlings twice weekly in } \\
\text { infested areas to identify high } \\
\text { leafmining activity before it } \\
\text { becomes restrictive to rapid plant } \\
\text { growth. Insecticide use can be } \\
\text { justified when an average of }>1 \\
\text { mine per plant is found during } \\
\text { scouting of young plants. Protection } \\
\text { of wrapper leaves may require more } \\
\text { frequent scouting and insecticide } \\
\text { treatments. }\end{array}$ \\
\hline \hline
\end{tabular}

Table 6. Leafminers

\begin{tabular}{||l|l||}
\hline \hline $\begin{array}{c}\text { Management } \\
\text { Options }\end{array}$ & \multicolumn{1}{c|}{ Recommendation } \\
\hline Notes & $\begin{array}{l}\text { This insect developed resistance to } \\
\text { most commonly used insecticides } \\
\text { labeled for its control prior to 1990. } \\
\text { The use of the effective insecticides } \\
\text { cyromazine and abamectin should } \\
\text { be strictly rotated according to the } \\
\text { label to manage resistance } \\
\text { development. The use of selective } \\
\text { insecticides, such as SpinTor and } \\
\text { Proclaim, for armyworm and } \\
\text { cabbage looper control also } \\
\text { provides some control of leafminer } \\
\text { populations and are soft on most } \\
\text { beneficial insects. }\end{array}$ \\
\hline $\begin{array}{l}\text { Natural } \\
\text { Enemies }\end{array}$ & $\begin{array}{l}\text { Tiny wasp parasitoids attack the } \\
\text { larvae and are quite effective at } \\
\text { reducing leafminer populations } \\
\text { unless they are eliminated by the } \\
\text { use of broad spectrum insecticides. }\end{array}$ \\
\hline Seedcorn \\
Vontrols
\end{tabular}

The light gray to grayish-brown fly (Figure 16) is $3 / 16$ to $1 / 4$ in. long. Their wings are held crossed over the abdomen at rest. Eggs are less than 1/16 in. long, narrow, and pale white. Full grown maggots (Figure 17) are $1 / 4$ in. long, pale yellow, and legless. They have a tough cuticle, a pointed head with dark retractable mouth hooks, and a bluntly truncated abdomen terminated with two brown to black spiracles. The dark brown, $3 / 16$ to $1 / 4$ in. long, barrel-shaped puparia are found in soil. 


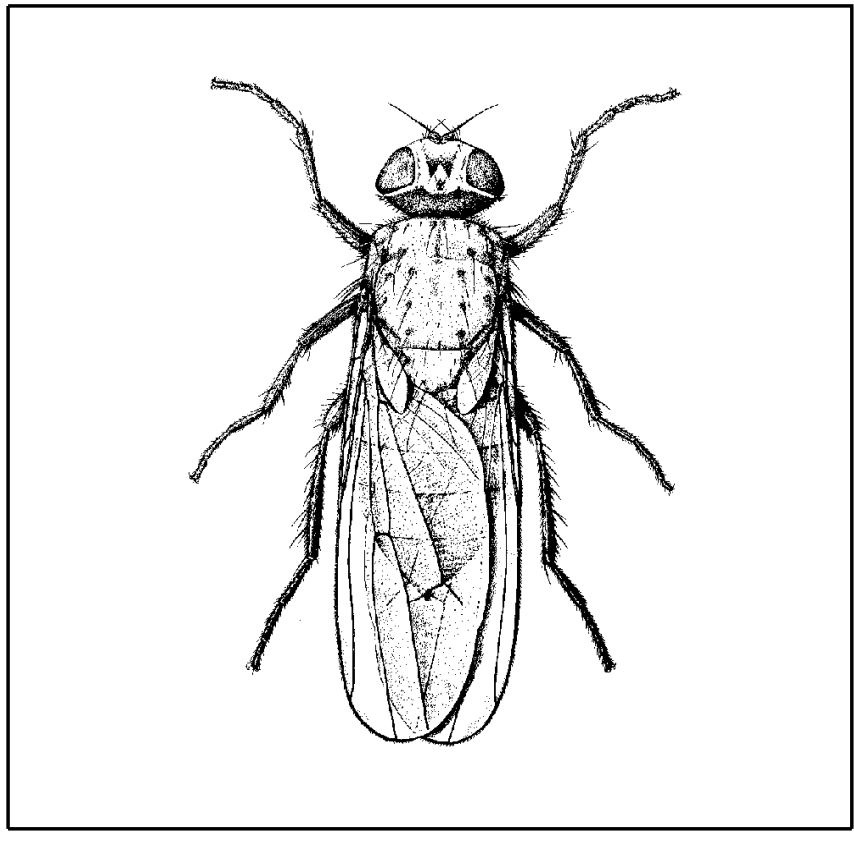

Figure 16. Seedcorn maggot adult.

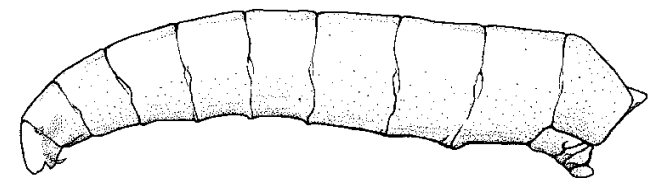

Figure 17. Seedcorn maggot larva.

\section{Biology}

Adults feed on pollen, nectar and other moisture sources. Eggs are deposited in soil cracks, under clods, or on decaying vegetation. Larvae feed on seedlings beneath the soil surface. The pupal stage is passed in the soil within the cuticle of the last instar larvae. Adults emerge in 12 to 15 days for a generation time of about 21 days.

\section{Damage}

Larvae attack seedlings before they emerge from soil. Damage can result in stand loss or delayed growth. Seeds in cool, moist soil or where green cover crop has been recently incorporated are more likely to be attacked.
Table 7. Seed corn maggot

\begin{tabular}{||l|l||}
\hline \multicolumn{1}{||c|}{$\begin{array}{c}\text { Management } \\
\text { Options }\end{array}$} & \multicolumn{1}{c|}{ Recommendation } \\
\hline Thresholds & $\begin{array}{l}\text { The soil profile around the seed } \\
\text { furrow in areas of poor emergence } \\
\text { should be carefully examined to } \\
\text { detect damaged seedlings and } \\
\text { possible pests. }\end{array}$ \\
\hline Notes & $\begin{array}{l}\text { Insecticides are available for pre- } \\
\text { and at-plant broadcast, banded and } \\
\text { in-furrow applications. Applications } \\
\text { work best when applied at planting } \\
\text { in combinations of in the seed } \\
\text { furrow and mixed with soil covering } \\
\text { the seed furrow. }\end{array}$ \\
\hline $\begin{array}{l}\text { Cultural } \\
\text { Controls }\end{array}$ & $\begin{array}{l}\text { Planting to warmer soils reduces } \\
\text { chances for seed corn maggot } \\
\text { damage. Decaying vegetation is } \\
\text { attractive to the adults, so fallowed } \\
\text { fields should be disked to prepare } \\
\text { for planting at least 30 days before } \\
\text { planting to allow time for these flies } \\
\text { to complete their development. }\end{array}$ \\
\hline \hline
\end{tabular}

\section{Cucumber Beetles}

\section{Description}

Adult banded cucumber beetles (Diabrotica balteata LeConte) (Figure 18) are small (1/4 to 3/8 in. long) and oval-shaped with a dirty yellow to dark green thorax and abdomen. The yellow transverse bands across the wing covers (elytra) and red to reddish-brown heads serve to separate them from the southern or spotted root worm adults (Diabrotica undecimpunctata howardi Barber) which have 12 black spots in 3 rows of 4 spots each across their elytra. The third tarsal segment on all legs in both species is laterally swollen into two lobes with the last (fourth) tarsal segment originating from between the lobes. Both species produce small, oval-shaped, pale yellow eggs. The white, elongate and soft bodied larvae have three pairs of minute legs. Larvae are indistinguishable between the two species. The white to pale green pupae are found within loosely woven cocoons in the soil. 


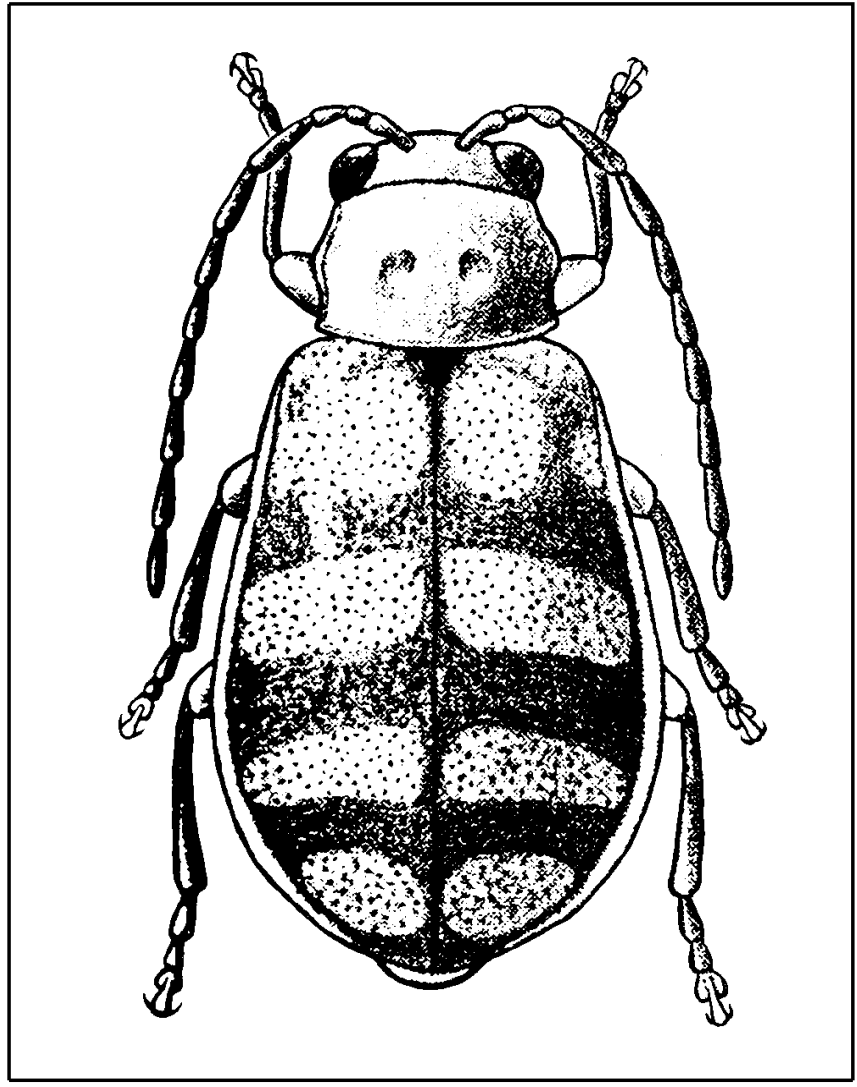

Figure 18. Banded cucumber beetle.

\section{Biology}

Adults feed on leaves of most vegetable crops. Adults enter the soil to deposit eggs in clusters of up to 12 near roots of host crops. Larvae emerge in 6 to 8 days and feed on roots and other soft tissue at the base of plants. Larvae complete development in 15 to 22 days feeding on corn roots. Adults emerge in 16 to 20 days. Banded cucumber beetles complete development in 35 to 50 days.

\section{Damage}

Cucumber beetles are found throughout Florida, with the banded species more common in central and south Florida and the spotted one more common in northern Florida. While preferring to feed on weeds in the genus Amaranthus, adults can cause serious foliar damage to leafy vegetables. Adult feeding produces irregular shaped holes and window panes in leaf tissue. Banded cucumber beetles enter fields by the many hundreds to thousands from disturbed weed reservoirs. Young plants are at higher risk because adults can quickly destroy the terminal region causing death or suckering of the surviving plant. Delayed growth and stand loss can result from heavy feeding damage to seedlings. Feeding damage to older leaves is evidenced by notched leaves, window paning and irregular patches with only the veins remaining.

Table 8. Cucumber beetles

\begin{tabular}{|c|c|}
\hline $\begin{array}{c}\text { Management } \\
\text { Options }\end{array}$ & Recommendation \\
\hline $\begin{array}{l}\text { Scouting/ } \\
\text { Threshold }\end{array}$ & $\begin{array}{l}\text { Seedling plants are most sensitive to } \\
\text { adult feeding. Look for adults, } \\
\text { feeding damage and thread-like or } \\
\text { oily spot of fecal material at feeding } \\
\text { sites while scouting for caterpillars. }\end{array}$ \\
\hline Notes & $\begin{array}{l}\text { Chemical control of adults is through } \\
\text { contact or bait insecticides. This } \\
\text { latter type selectively treat the } \\
\text { beetles as they eat the baits. }\end{array}$ \\
\hline $\begin{array}{l}\text { Natural } \\
\text { Enemies }\end{array}$ & $\begin{array}{l}\text { Several predacious insects and } \\
\text { spiders prey on these insects, but } \\
\text { migration of large numbers can } \\
\text { quickly overwhelm the natural enemy } \\
\text { complex, particularly in seedling } \\
\text { stage crops. }\end{array}$ \\
\hline $\begin{array}{l}\text { Resistant } \\
\text { Varieties }\end{array}$ & $\begin{array}{l}\text { 'Valmaine' and 'Floricos } 83 \text { ' are two } \\
\text { lettuce varieties that exhibit } \\
\text { resistance to adult cucumber beetle } \\
\text { feeding. }\end{array}$ \\
\hline $\begin{array}{l}\text { Cultural } \\
\text { Controls }\end{array}$ & $\begin{array}{l}\text { Control of cucumber beetle infested } \\
\text { weeds on ditch banks and } \\
\text { surrounding fields should be timed so } \\
\text { that beetles are not forced to look for } \\
\text { food during sensitive periods in leafy } \\
\text { vegetable development. }\end{array}$ \\
\hline
\end{tabular}

\section{Seedcorn Beetles}

\section{Description}

Adult seedcorn beetle, Stenolophus lecontei (Chaudoir) (Figure 19), is dark brown below and yellowish- to reddish-brown above. Their wing covers are black with lighter colored bands around margins. Slender seedcorn beetle adults, Clivina impressifrons LeConte, are chestnut-brown with flattened front legs. Both beetles are in the range of $1 / 4$ to 5/16 in. long. Neither has mandibles with a hardened, raised area (including teeth or ridges) near base. Their tiny, white, oval-shaped eggs are deposited in tunnels in the soil. Larvae reach 9/16 in. long and are pale yellow to light brown with three 
pairs of short true legs. The head and top of first thoracic segment are darker than the abdomen. Newly molted pupae are pale white, but quickly turn dark brown or black within cells in the soil. Pupae are naked with appendages and wing buds completely visible. Seedcorn beetles complete a generation in 28 to 81 days at $72^{\circ} \mathrm{F}$.

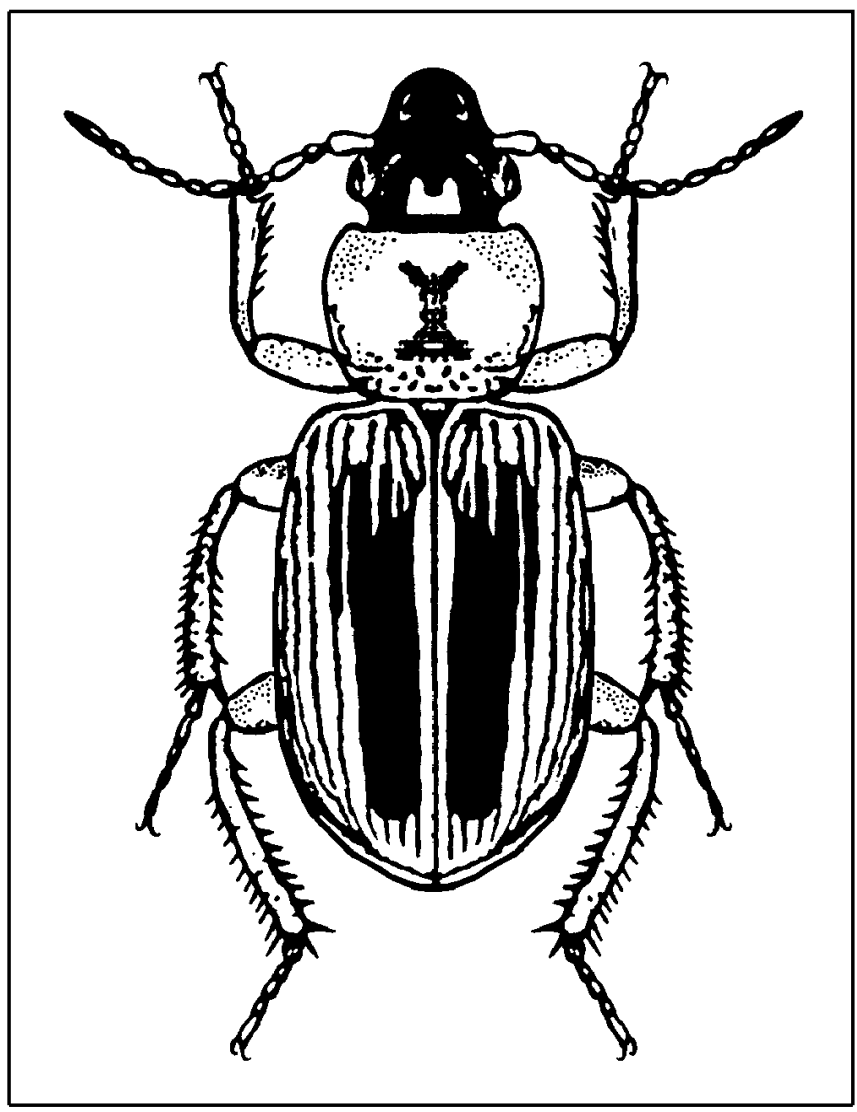

Figure 19. Seedcorn beetle adult.

\section{Biology}

Larvae and adults mostly eat insects, live or dead, but will attack seeds of germinated but not emerged seedlings of several grains, vegetables and weeds in soil. Their development is highly variable depending on food availability. Larvae emerge in 3 to 12 days and complete development in 18 to 56 days at $72^{\circ} \mathrm{F}$. Adults emerge in 7 to 13 days at $72^{\circ} \mathrm{F}$.

\section{Damage}

They are found more commonly on heavy, moist soil where seed germination may be delayed. Larvae and adults both travel through soil and across the soil surface to get to seeds and seedlings. Their attack results in an uneven or poor stand. Damage on the high organic soils is also associated with planting to previously fallowed, uncultivated fields. Other species in this family share similar habits and damage germinating seeds and pre-emerged seedlings when planted to newly cleared or other lands that have been out of production.

Table 9. Seedcorn beetles

\begin{tabular}{||l|l||}
\hline \hline $\begin{array}{c}\text { Management } \\
\text { Options }\end{array}$ & \multicolumn{1}{c||}{ Recommendation } \\
\hline $\begin{array}{l}\text { Scouting/ } \\
\text { Thresholds }\end{array}$ & $\begin{array}{l}\text { Adult populations can be monitored } \\
\text { with pitfall and black light traps. } \\
\text { Most commercial leafy vegetable } \\
\text { production uses coated seeds and } \\
\text { most of the damage is targeted on } \\
\text { germinated seeds and seedlings. } \\
\text { The soil profile around the seed } \\
\text { furrow in areas of poor emergence } \\
\text { should be carefully examined to } \\
\text { detect damaged seedlings and find } \\
\text { attacking larval and adult stages. }\end{array}$ \\
\hline Notes & $\begin{array}{l}\text { Insecticides are available for pre- } \\
\text { and at-plant broadcast, banded and } \\
\text { in-furrow applications. Applications } \\
\text { work best when applied at planting in } \\
\text { combinations of in the seed furrow, } \\
\text { mixed with soil covering the seed } \\
\text { furrow and sprayed on the soil } \\
\text { surface above the drill line. }\end{array}$ \\
\hline Cultural & $\begin{array}{l}\text { Field preparation on fallowed fields } \\
\text { should be concluded as early as } \\
\text { possible before planting to reduce } \\
\text { the chance of attack by these } \\
\text { beetles, as well as by seed corn } \\
\text { maggots. }\end{array}$ \\
\hline \hline
\end{tabular}

\section{Wireworms or Click Beetles}

\section{Description}

The adult stage (Figure 20) of this insect is a slender, somewhat flattened, medium to dark brown or gray beetle between $1 / 2$ and $7 / 8$ in. long. The exoskeleton is smooth or with very short hairs and has a large tooth-like projection between the rear legs that fits into a groove on the undersurface of the abdomen. These beetles feign death when disturbed and can then right themselves from their backs by quick flexion at the juncture of the thorax and abdomen. The larvae or wireworm (Figure 21) has a narrow, hardened, creamy yellow to orange-brown, tubular body. Characteristic hardened projections on 
the next to last abdominal segment can be used to identify them to species. They have three pairs of short true legs and no prolegs and can reach 1 1/4 in. long. Pupae are naked with legs, antennae and wing buds completely visible.

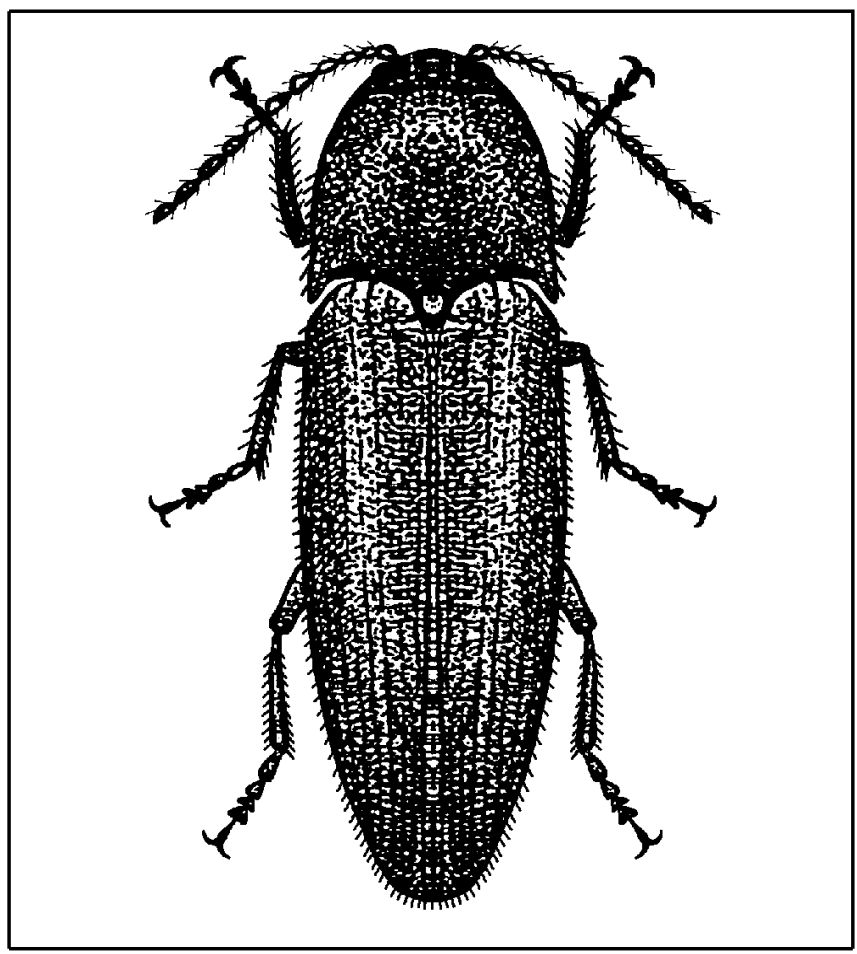

Figure 20. Wireworm adult.

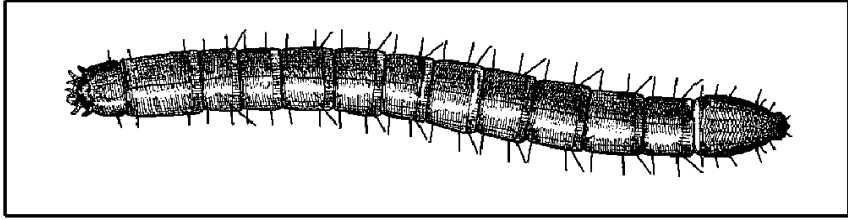

Figure 21. Wireworm larva.

\section{Biology}

Adults feed on living and decaying plant material and are frequently observed in plant axils and heads during the late spring. Eggs are deposited in soil near plant roots, particularly around grasses, during summer months. Wireworms take two to several years to complete larval development while feeding on seeds, roots, seedlings and decaying plant material. The pupal stage is passed in the soil from which adults emerge within 2 weeks.

\section{Damage}

Larvae attack seeds, roots and crowns of plants mostly below the soil surface. They chew into the base of plants and then hollow out the stem, eliminating the growing points. Young plants first exhibit severe wilting and desiccation of the youngest leaves. Plant death and stand loss quickly follow wilting symptoms.

Table 10. Wireworms

\begin{tabular}{|c|c|}
\hline $\begin{array}{c}\text { Management } \\
\text { Options }\end{array}$ & Recommendation \\
\hline $\begin{array}{l}\text { Scouting/ } \\
\text { Thresholds }\end{array}$ & $\begin{array}{l}\text { Soil within } 8 \text { in. diameter around } \\
\text { affected plants should be excavated } \\
\text { in search of larvae in or near these } \\
\text { plants. If infestation density is in } \\
\text { question, then fields should be } \\
\text { sampled for these pests to determine } \\
\text { the best treatment strategy before } \\
\text { crop is planted. Baits of oat, corn or } \\
\text { potato buried in fields and recovered } \\
\text { in } 2 \text { to } 3 \text { wk work well to monitor } \\
\text { wireworms. Average counts }>2 \text { per } \\
\text { bait are enough to recommend } \\
\text { treatment. }\end{array}$ \\
\hline Notes & $\begin{array}{l}\text { Insecticides are available for } \\
\text { pre-plant broadcast and at-plant } \\
\text { banded applications. Soil moisture } \\
\text { plays an important role in releasing } \\
\text { insecticides from their carriers, } \\
\text { consequently wireworm control in dry } \\
\text { soils is more difficult. Pre- or post- } \\
\text { plant watering of dry soils and } \\
\text { adequate mixing of insecticides with } \\
\text { the soil around and in the seed furrow } \\
\text { will help to improve control. }\end{array}$ \\
\hline $\begin{array}{l}\text { Natural } \\
\text { Enemies }\end{array}$ & $\begin{array}{l}\text { Birds such as cattle egrets that follow } \\
\text { farm equipment through the field can } \\
\text { eat many wireworms exposed during } \\
\text { field disking. }\end{array}$ \\
\hline $\begin{array}{l}\text { Cultural } \\
\text { Controls }\end{array}$ & $\begin{array}{l}\text { Leafy vegetables planted to weedy } \\
\text { fields, or in rotation from pasture or } \\
\text { sugarcane, are often exposed to very } \\
\text { large wireworm populations. Summer } \\
\text { flooding of fields is an effective } \\
\text { cultural control, providing it is } \\
\text { maintained for at least several weeks. } \\
\text { Water temperature should be above } \\
82^{\circ} \mathrm{F} \text { for maximum control. Rotation } \\
\text { through a cycle of rice has been } \\
\text { shown to eliminate the need for } \\
\text { wireworm treatment in the } \\
\text { subsequent crop. }\end{array}$ \\
\hline
\end{tabular}




\section{Thrips, Frankliniella spp.}

\section{Description}

Adults (Figure 22) are narrow, pale yellow to brown to black, and approximately $1 / 16 \mathrm{in}$. long with fine fringed wings held over their bodies at rest. The narrow whitish eggs are inserted into plant tissue. Larvae emerge in 3 days to feed in flowers or on leaf tissue.

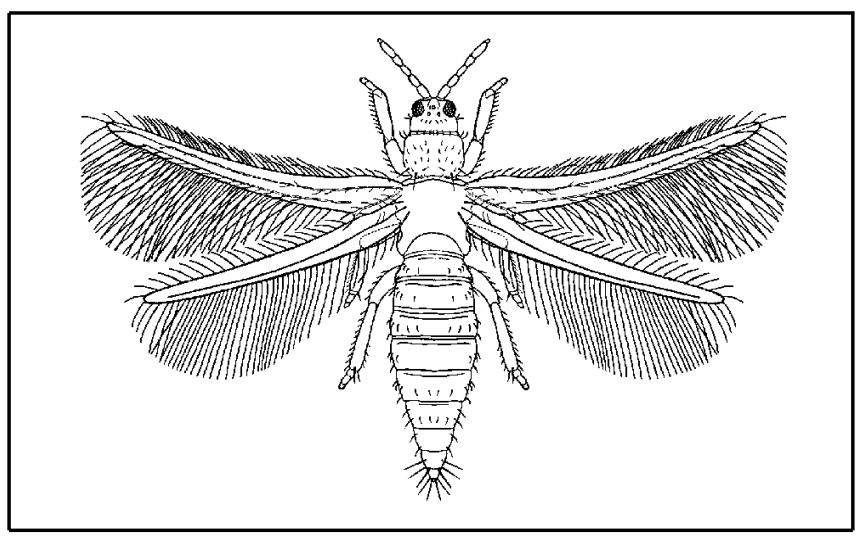

Figure 22. Thrips.

\section{Biology}

Adults and larvae feed using their short mouth parts to rupture and feed from epidermal cells. Larvae develop for two instars before entering the quiescent third instar. This larva travels to the soil, plant litter or other secluded location on the plant before molting into the immobile pupal stage. Thrips can complete a generation in 14 to 20 days. Most of the thrips feeding on leafy vegetables develop elsewhere, frequently on flowering weeds surrounding fields.

\section{Damage}

Adult thrips often move into fields from neighboring fields, road sides or canal banks by the many thousands within hours when their previous host plants senesce or are disked or mowed. Large numbers of thrips can damage leaves by excessive feeding. Areas of concentrated feeding appear more reflective or silvery in color. Such damage may turn into larger necrotic lesions in the postharvest environment. Another potential source of thrips damage in Florida is the transmission of tomato spotted wilt (TSWV) and escarole necrosis viruses (ENV) to leafy vegetables from ditch and road side weed or crop reservoirs. Researchers at the University of Hawaii indicate that symptoms of tomato spotted wilt in lettuce are many tiny spots on the younger leaves, and stunted plants which fail to head and then rot in the field. Symptoms also include bronzing, downward leaf curling, and extensive tissue necrosis. Plants collapse and die in one to two weeks after initial symptoms are detected. Leaves formed after infection by ENV are increasingly stunted resulting in a rosette of tiny leaves. Affected leaves become increasingly chlorotic and are quite visible within the field. ENV also ultimately kills the plant.

Table 11. Thrips

\begin{tabular}{|c|c|}
\hline $\begin{array}{c}\text { Management } \\
\text { Options }\end{array}$ & Recommendation \\
\hline $\begin{array}{l}\text { Scouting/ } \\
\text { Thresholds }\end{array}$ & $\begin{array}{l}\text { Look for thrips at the base of the } \\
\text { leaves between the veins. Treatment } \\
\text { may be warranted if numerous thrips } \\
\text { are present and feeding is causing } \\
\text { significant damage, or if crop is in } \\
\text { area known for virus outbreaks. They } \\
\text { are attracted to the colors white, } \\
\text { yellow, and blue and can often be } \\
\text { seen by the thousands on vehicles } \\
\text { in the affected area. Sticky cards or } \\
\text { plastic cups in these colors can be } \\
\text { placed in or around fields to detect } \\
\text { thrips movement into fields. }\end{array}$ \\
\hline Notes & $\begin{array}{l}\text { Insecticides are available for foliar } \\
\text { applications. While insecticides help } \\
\text { to reduce secondary spread of virus } \\
\text { by thrips, it will not prevent primary } \\
\text { infection of fields with virus spread } \\
\text { from surrounding flowering weeds or } \\
\text { infected crop reservoirs. }\end{array}$ \\
\hline $\begin{array}{l}\text { Natural } \\
\text { Enemies }\end{array}$ & $\begin{array}{l}\text { Thrips have numerous insect and } \\
\text { mite predators that attack them in } \\
\text { mostly field border situations and } \\
\text { other flowering crops where little or } \\
\text { no insecticide treatments are made. } \\
\text { However, their presence in leafy } \\
\text { vegetables would not be able to } \\
\text { prevent much virus transmission to } \\
\text { these crops. }\end{array}$ \\
\hline $\begin{array}{l}\text { Resistant } \\
\text { Varieties }\end{array}$ & $\begin{array}{l}\text { No resistance to tomato spotted wilt } \\
\text { virus is currently available in } \\
\text { commercial lettuce varieties. } \\
\text { Escarole and endive are quite } \\
\text { susceptible to escarole necrosis } \\
\text { virus. }\end{array}$ \\
\hline
\end{tabular}


Table 11. Thrips

\begin{tabular}{|c|c|}
\hline $\begin{array}{c}\text { Management } \\
\text { Options }\end{array}$ & Recommendation \\
\hline $\begin{array}{l}\text { Cultural } \\
\text { Controls }\end{array}$ & $\begin{array}{l}\text { Control weeds prior to their flowering } \\
\text { cycle to prevent thrips build up on } \\
\text { ditch banks and roadsides } \\
\text { surrounding fields. Avoid planting } \\
\text { leafy vegetables near areas with } \\
\text { known tomato spotted wilt virus } \\
\text { reservoirs during seasons of major } \\
\text { thrips movement (i.e., spring and } \\
\text { fall). Avoid mowing or disking } \\
\text { flowering weeds in these areas } \\
\text { surrounding leafy vegetable crops } \\
\text { during the season in areas known for } \\
\text { problems with escarole necrosis } \\
\text { virus. }\end{array}$ \\
\hline
\end{tabular}

\section{Aphids}

\section{Description}

Several species of aphids are encountered in leafy vegetable crops. Green peach aphids, Myzus persicae (Sulzer) (Figure 23), are pale yellow to green with winged forms being slightly darker. This aphid has distinctive swollen areas (tubercles) at the base of the antennae that converge towards each other. Potato aphids, Macrosiphum euphorbiae (Thomas) (Figure 24), are either pink or green and are much bigger than green peach aphids. Their antennal tubercles do not converge toward the midline. Potato aphids have long legs, antennae and cornicles. This aphid stays together and forms dense colonies on the undersides of leaves. Uroleucon pseudambrosiae (Olive) is the largest of these aphids and is commonly rusty orange to dark red. They multiply quickly under leaf surfaces and their dark color makes them readily visible to inspectors. Their appendages are long as in the potato aphid.

\section{Biology}

Adult and immature aphids feed on phloem sap sucked from leaves and stems through their long piercing-sucking mouth parts. Excess water and sugars are voided from the body through the cornicles. These deposits (honeydew) on leaves serve as a source of food for sooty mold fungi, ants, sap beetles and flies. Winged or wingless adult females deposit live nymphs, skipping the external egg stage

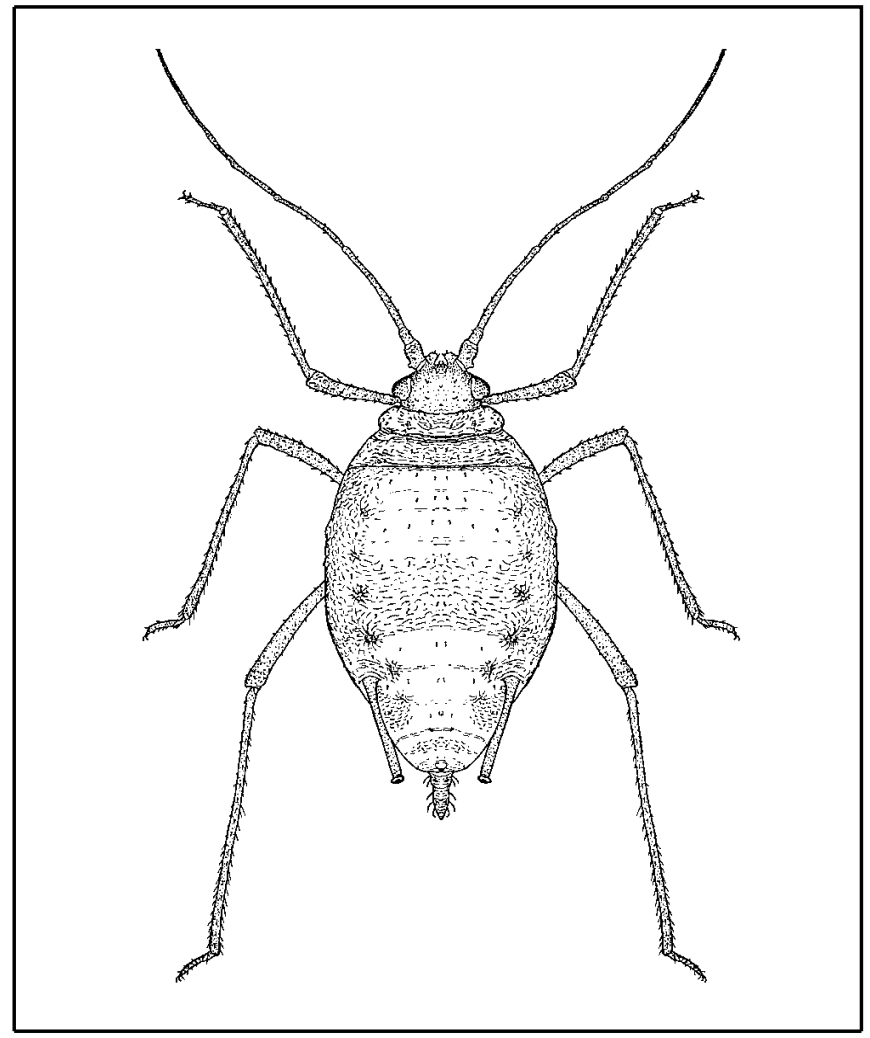

Figure 23. Green peach aphid.

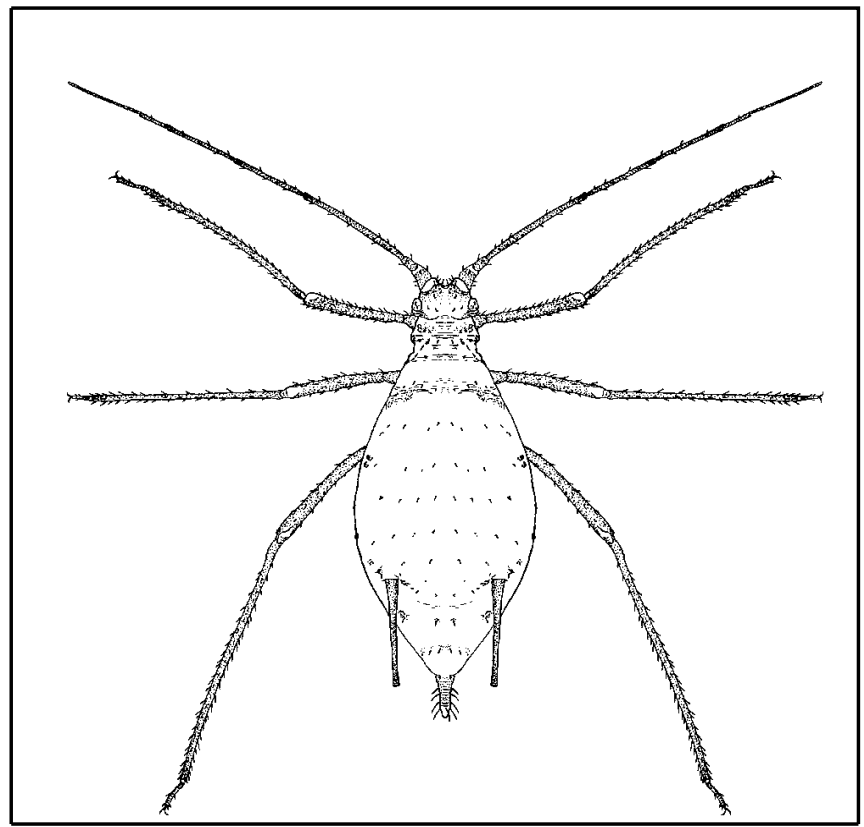

Figure 24. Potato aphid.

in Florida. Adults produce from 3 to 5 nymphs per day for up to several weeks. This allows for rapid population development. The nymphs pass through several instars before molting into adults in 7 to 10 days. There is no pupal stage in aphids. Green peach aphids usually spread out on leaves unless densities are very high. Potato aphids and U. pseudambrosiae 
aphids form dense colonies with adults and nymphs in close proximity to one another and kick their legs when disturbed.

\section{Damage}

Aphids have become a greater problem for winter and spring leafy vegetable crops during the last five years. Heavy aphid pressure on seedlings can reduce vigor and stunt plants. Honeydew from aphids produces a sticky mess inside heads and encourages sooty mold growth. However, aphid contamination of heads is considered the greater problem with counts of 20 live or 40 dead aphids on plants within a crate enough to throw the shipment out of grade. Aphids frequently move down older leaves and up into the developing heads of leafy vegetables where they experience more uniform temperature and humidity and protection from many natural enemies and insecticides. Aphids also transmit viruses to leafy vegetables, including lettuce mosaic and bidens mottle mosaic. These viruses can effect the color of the leaves and heads, as well as reduce the growth of young leaves within the heads. This latter symptom results in soft, infirm heads that are unmarketable as individual heads.

Table 12. Aphids

\begin{tabular}{|c|c|}
\hline $\begin{array}{c}\text { Management } \\
\text { Options }\end{array}$ & Recommendation \\
\hline $\begin{array}{l}\text { Scouting/ } \\
\text { Thresholds }\end{array}$ & $\begin{array}{l}\text { Look for aphids on the underside of } \\
\text { outer leaves and on both sides of } \\
\text { tender central leaves. After cupping, } \\
\text { heads should be opened if } \\
\text { necessary to look for aphid } \\
\text { colonization. Treat when aphids are } \\
\text { found to be reproducing, } \\
\text { particularly when second and later } \\
\text { generation wingless females have } \\
\text { started reproduction. }\end{array}$ \\
\hline
\end{tabular}

Table 12. Aphids

\begin{tabular}{|c|c|}
\hline $\begin{array}{c}\text { Management } \\
\text { Options }\end{array}$ & Recommendation \\
\hline Notes & $\begin{array}{l}\text { Aphid populations are easier to } \\
\text { control before the plants begin to } \\
\text { cup. Insecticides are available for } \\
\text { post-emergence foliar treatments. } \\
\text { Contact insecticides have limited } \\
\text { impact as plants enter the cupping } \\
\text { stage. Chemicals with systemic or } \\
\text { translaminar penetrating activity are } \\
\text { essential for aphid control during } \\
\text { the cupping through harvest period. } \\
\text { While insecticides may help reduce } \\
\text { secondary spread of aphid } \\
\text { transmitted viruses, they do not } \\
\text { prevent primary infection of fields. }\end{array}$ \\
\hline $\begin{array}{l}\text { Natural } \\
\text { Enemies }\end{array}$ & $\begin{array}{l}\text { Many types of natural enemies may } \\
\text { control these aphids under low } \\
\text { insecticide input situations. } \\
\text { However, these aphids reproduce } \\
\text { quickly and move into protected } \\
\text { areas of the plants, thereby greatly } \\
\text { reducing the potential impact of } \\
\text { their predators and parasitoids in } \\
\text { older stage plants. Pathogens kill } \\
\text { many winged adults before they } \\
\text { begin producing nymphs. }\end{array}$ \\
\hline $\begin{array}{l}\text { Cultural } \\
\text { Controls }\end{array}$ & $\begin{array}{l}\text { Field disking and destruction of crop } \\
\text { residues are important for control of } \\
\text { all caterpillar, aphid and leafminer } \\
\text { pests of leafy vegetables to reduce } \\
\text { their migration into nearby crops. }\end{array}$ \\
\hline
\end{tabular}




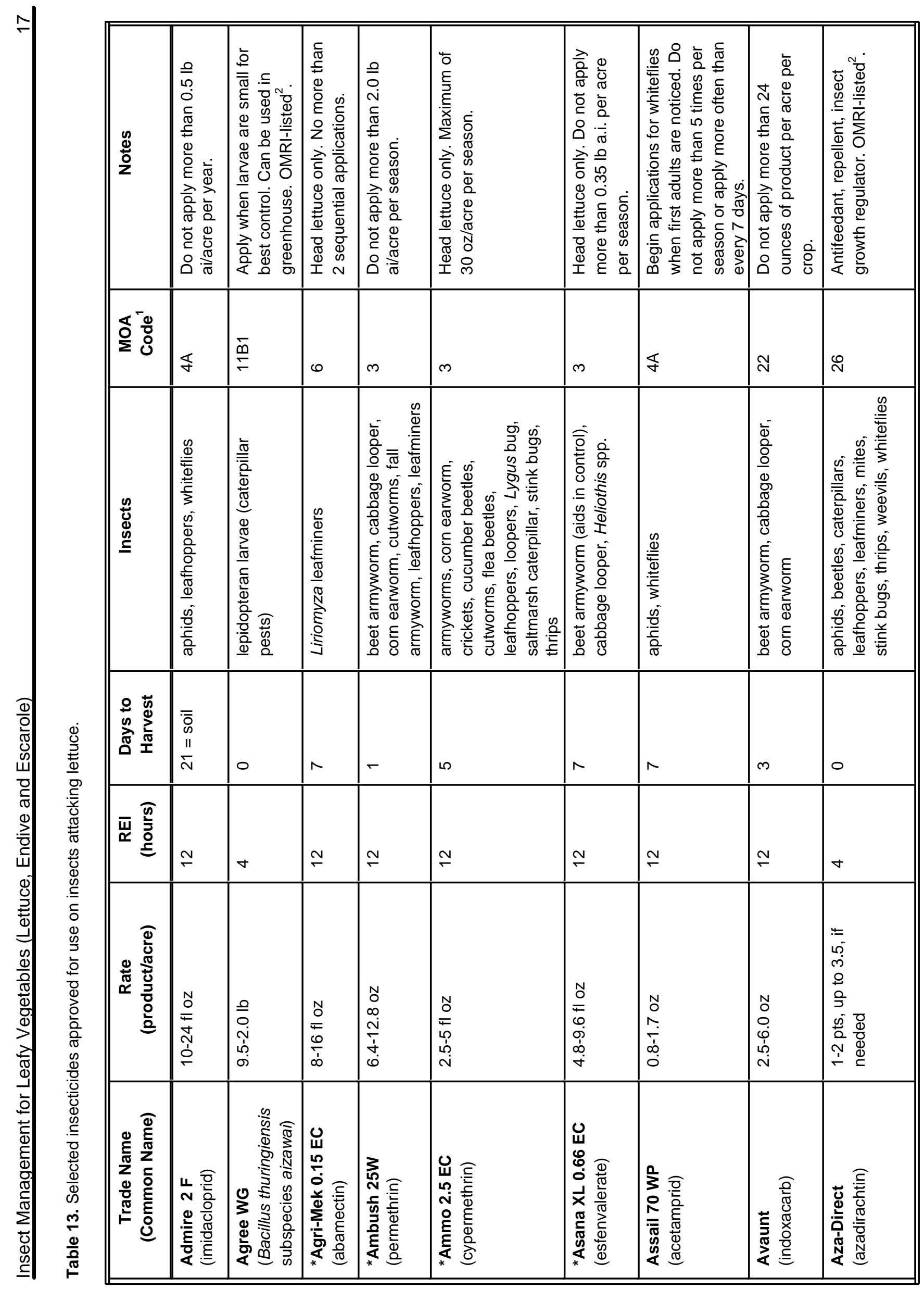




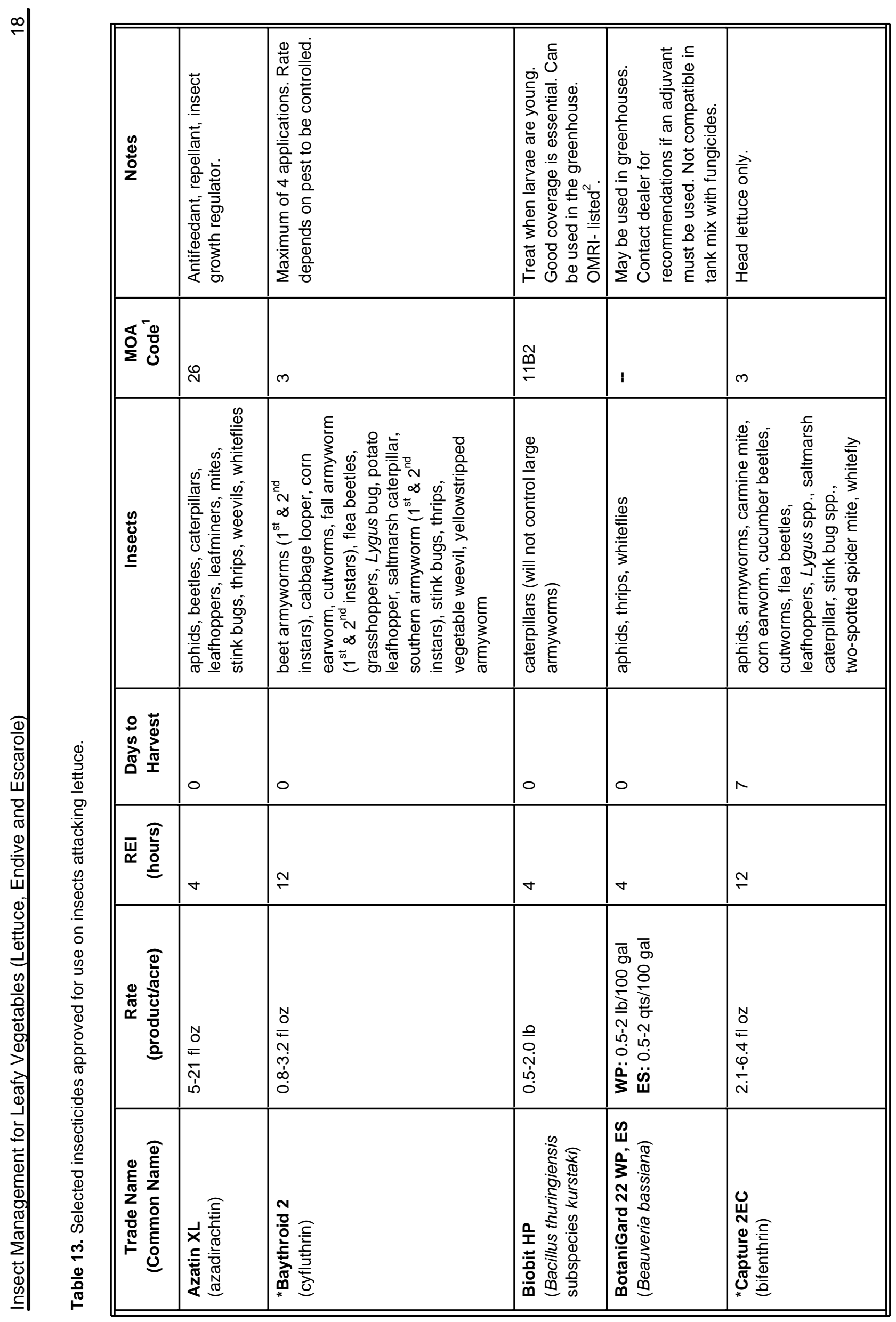




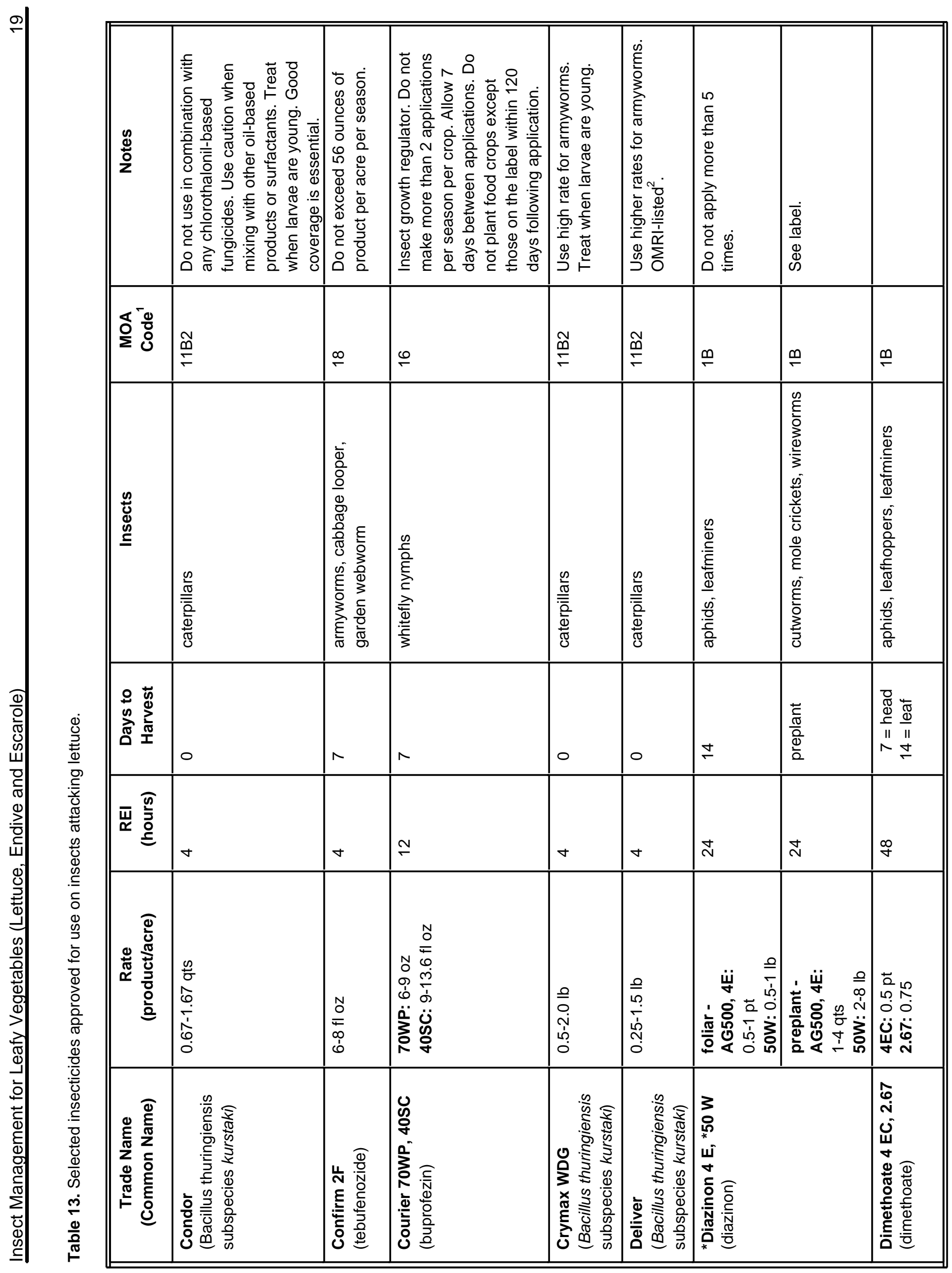




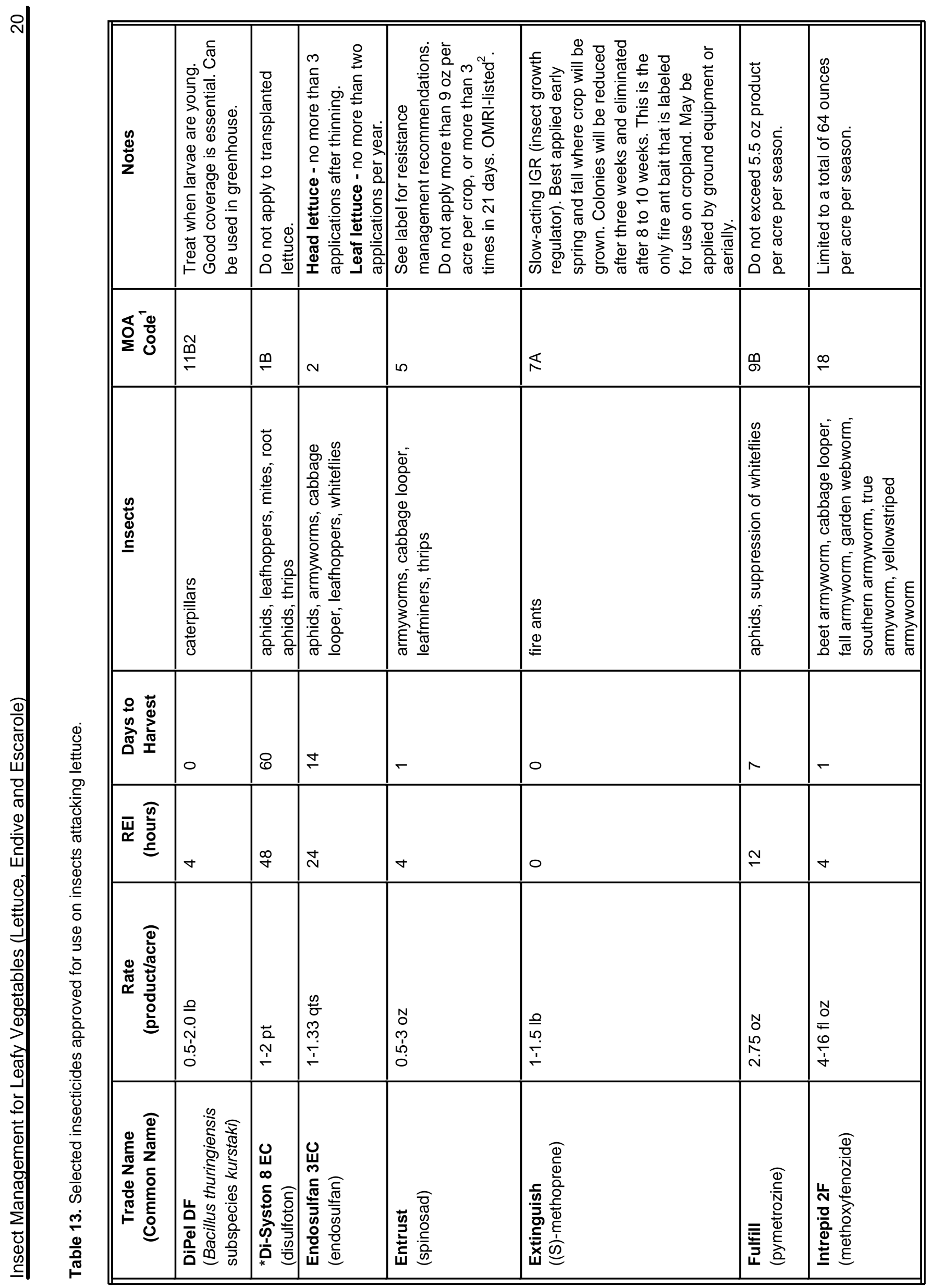




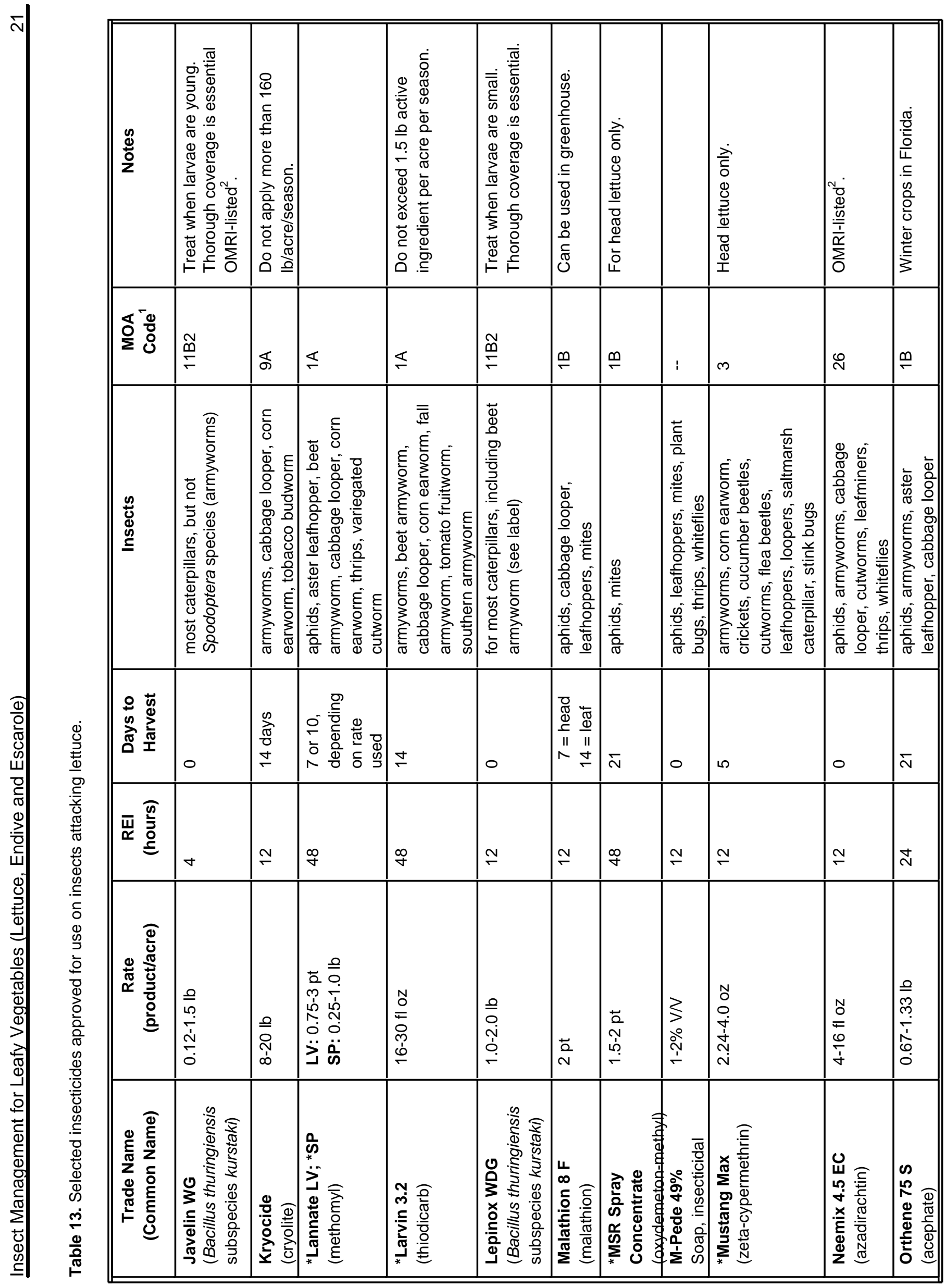




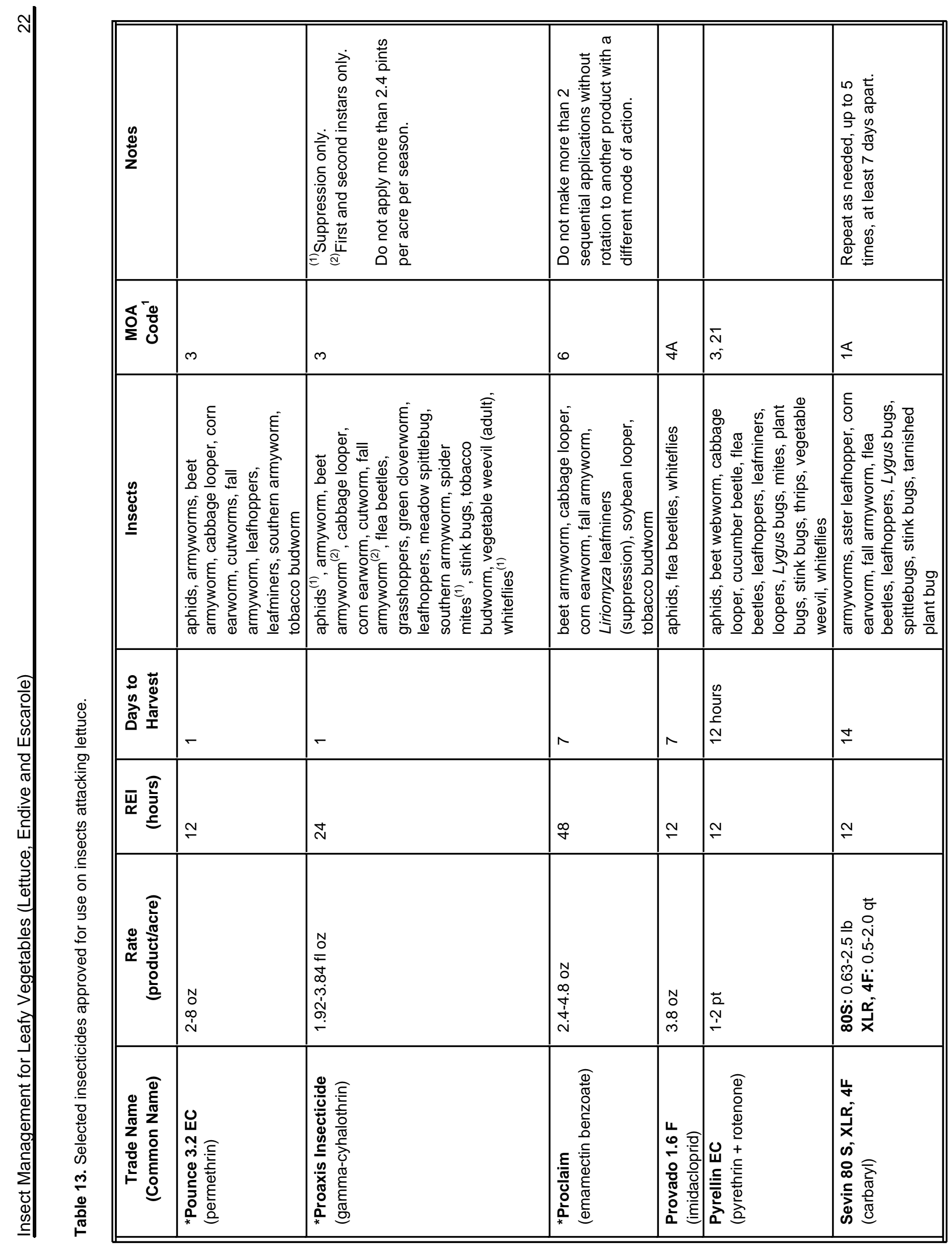




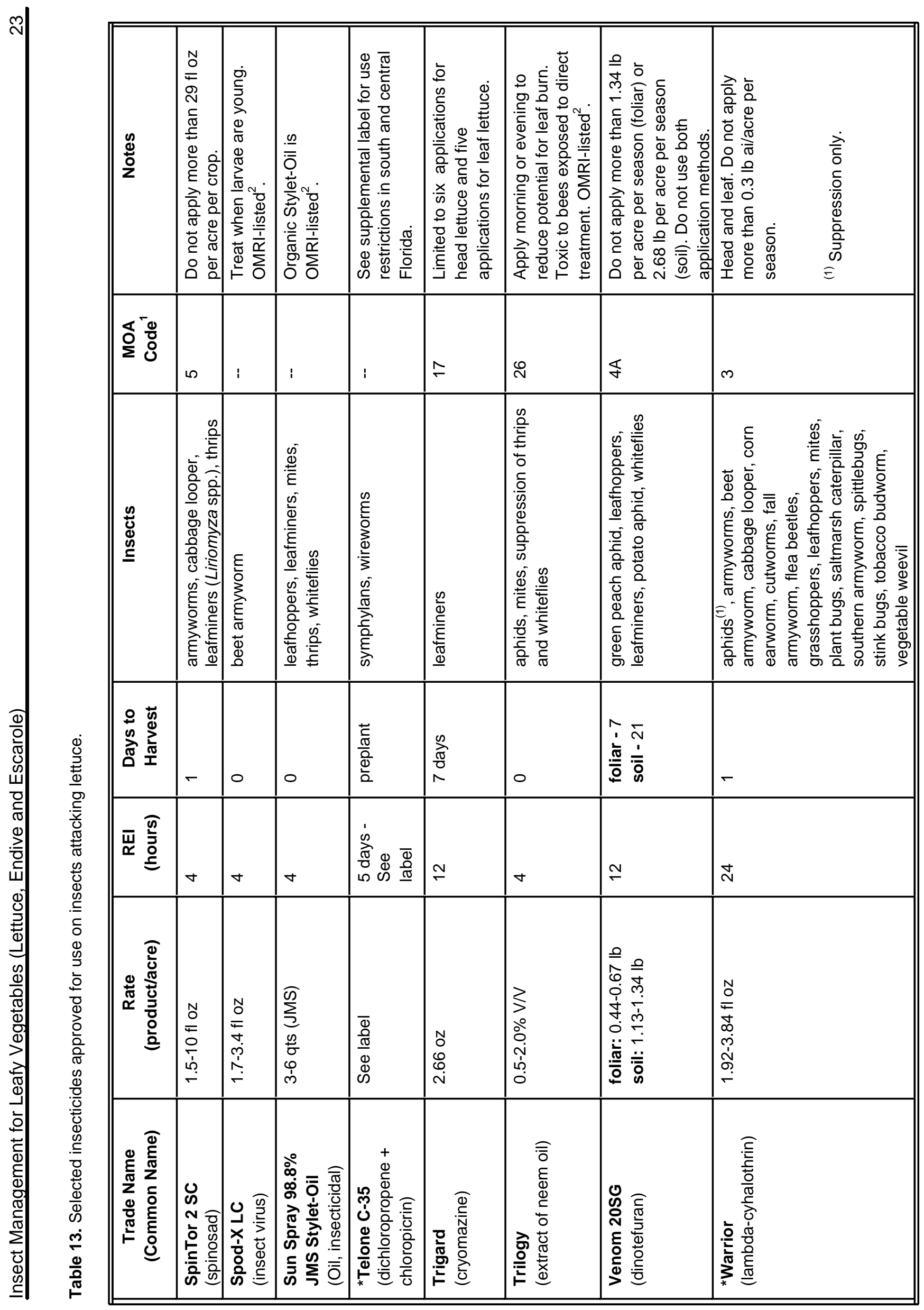




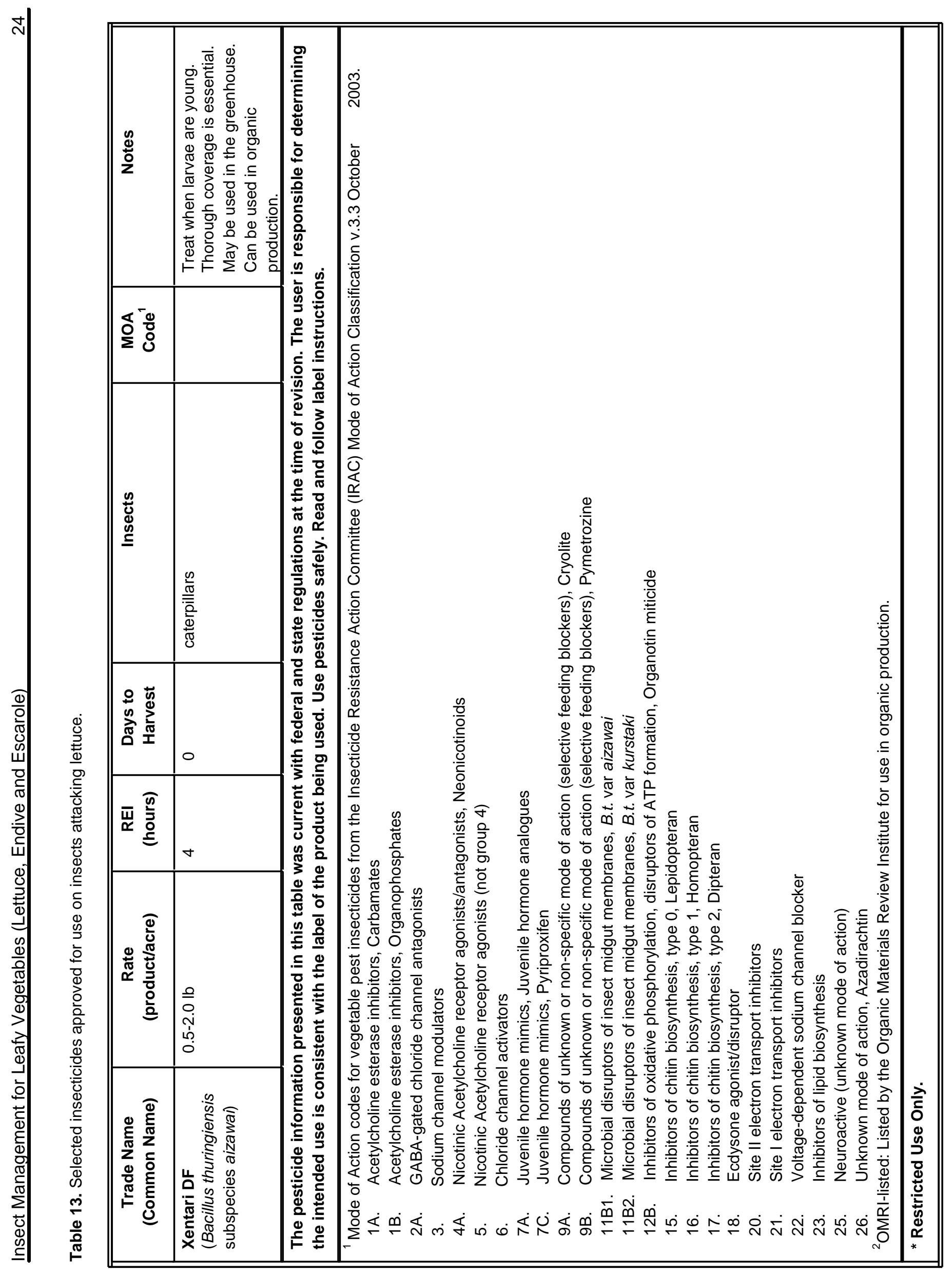




\begin{tabular}{|c|c|c|c|c|c|c|c|c|c|c|}
\hline & $\begin{array}{l}\stackrel{g}{\$} \\
\stackrel{0}{2}\end{array}$ & 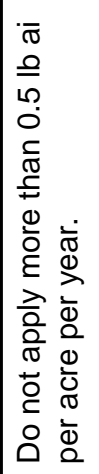 & 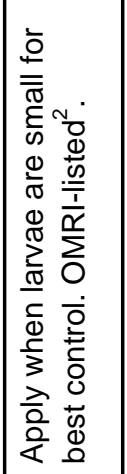 & 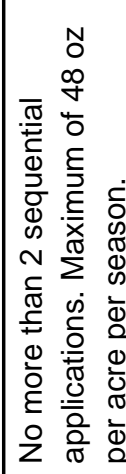 & 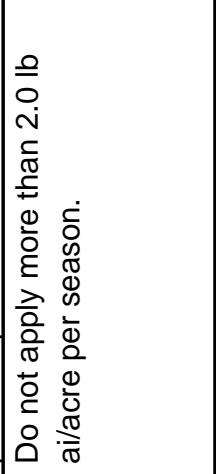 & 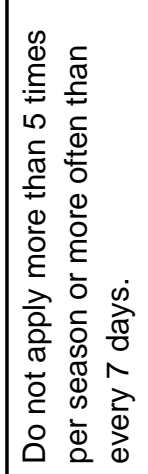 & 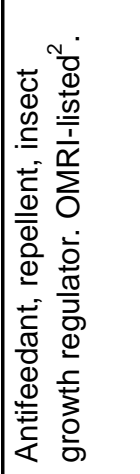 & 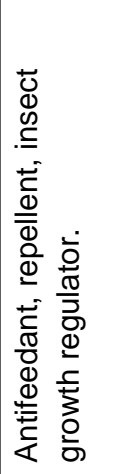 & 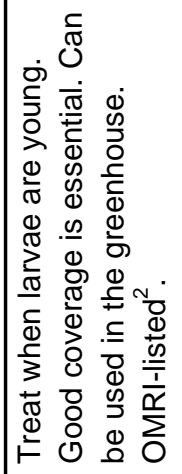 & 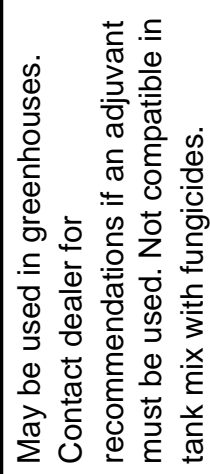 \\
\hline & 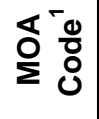 & $\Varangle$ & $\stackrel{\bar{m}}{\underline{\mp}}$ & 0 & $m$ & $\Varangle$ & $\stackrel{N}{N}$ & $\stackrel{N}{N}$ & $\underset{\infty}{\stackrel{N}{\mp}}$ & i \\
\hline$\frac{0}{\circ}$ & 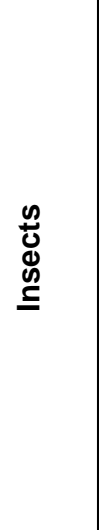 & 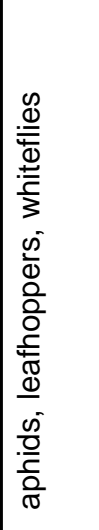 & 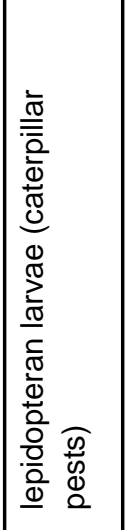 & 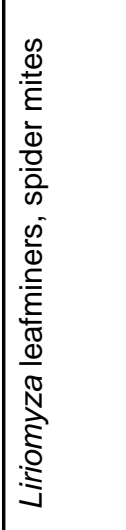 & 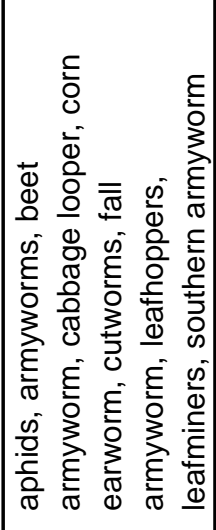 & 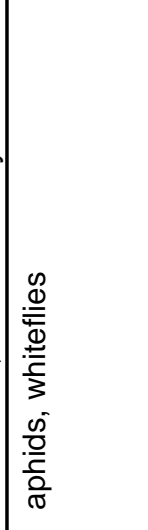 & 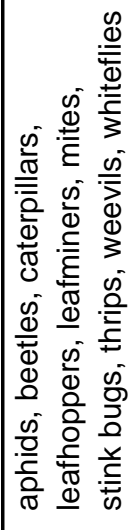 & 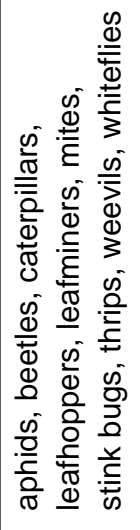 & 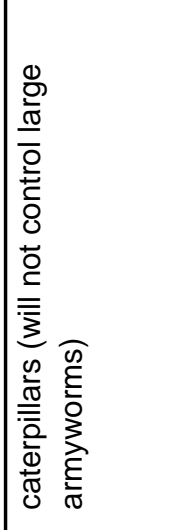 & 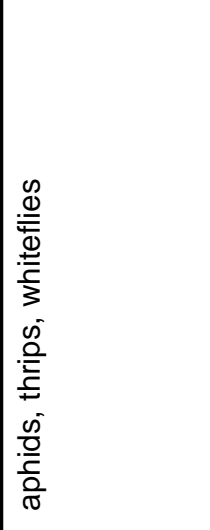 \\
\hline 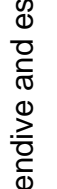 & 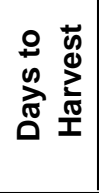 & $\begin{array}{l}\overline{\bar{o}} \\
\dot{1} \\
\bar{N}\end{array}$ & 0 & 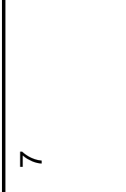 & - & $\wedge$ & 0 & 0 & 0 & 0 \\
\hline 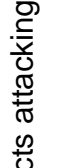 & 䙲 & $\cong$ & $\nabla$ & $\stackrel{\simeq}{\sim}$ & $\stackrel{N}{\simeq}$ & $\stackrel{\simeq}{\sim}$ & $\nabla$ & $\nabla$ & $\nabla$ & $\nabla$ \\
\hline $\begin{array}{l}= \\
\overline{2} \\
0 \\
0 \\
0 \\
0 \\
0 \\
0 \\
0 \\
0 \\
0 \\
0 \\
\frac{0}{0} \\
\frac{0}{0} \\
0\end{array}$ & 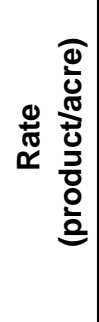 & 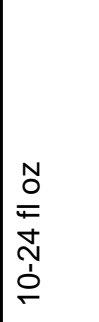 & $\begin{array}{l}\text { 응 } \\
\text { N } \\
\text { ம் } \\
0\end{array}$ & $\begin{array}{l}N \\
\frac{N}{E} \\
\frac{1}{0} \\
\frac{1}{\infty} \\
\infty\end{array}$ & 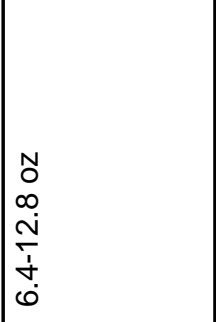 & $\begin{array}{l}N \\
0 \\
\\
\overline{1} \\
\infty \\
0 \\
0\end{array}$ & 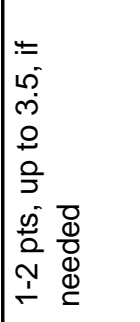 & $\begin{array}{l}\frac{N}{\infty} \\
\frac{N}{N} \\
\text { ம் }\end{array}$ & $\begin{array}{l}0 \\
0 \\
\text { N่ } \\
\text { مُ } \\
0\end{array}$ & 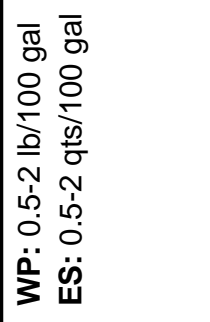 \\
\hline 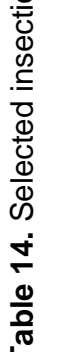 & 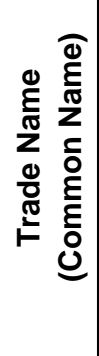 & 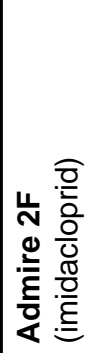 & 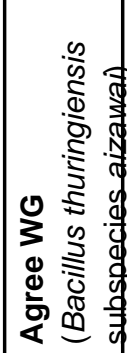 & 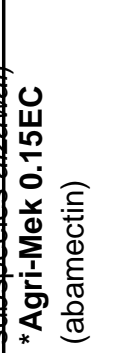 & 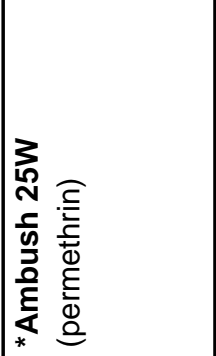 & 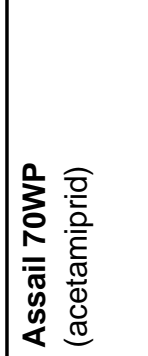 & 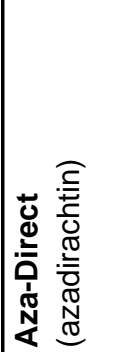 & 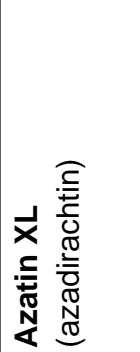 & 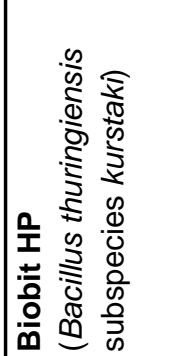 & 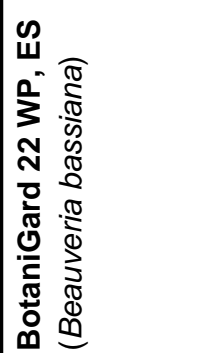 \\
\hline
\end{tabular}




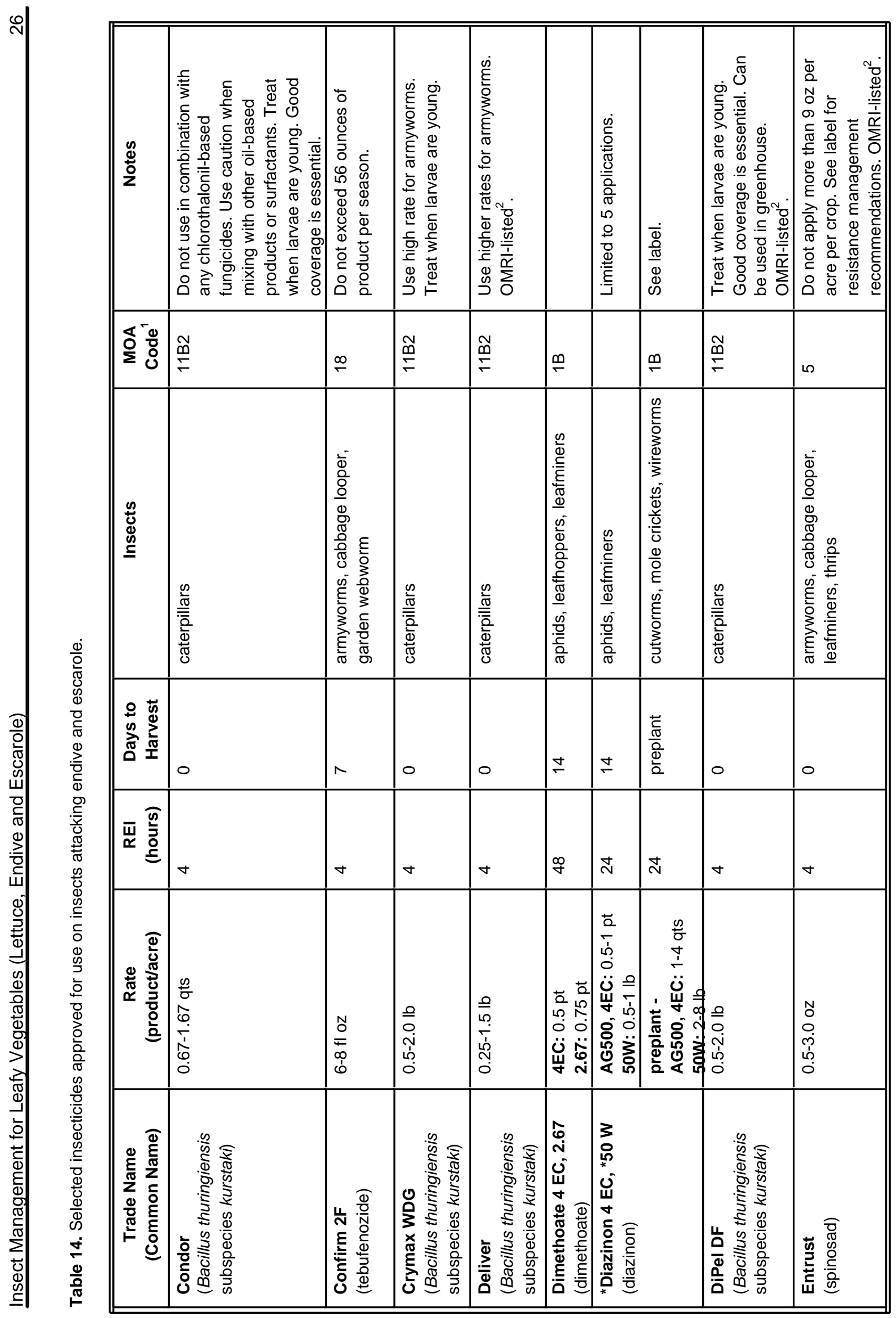




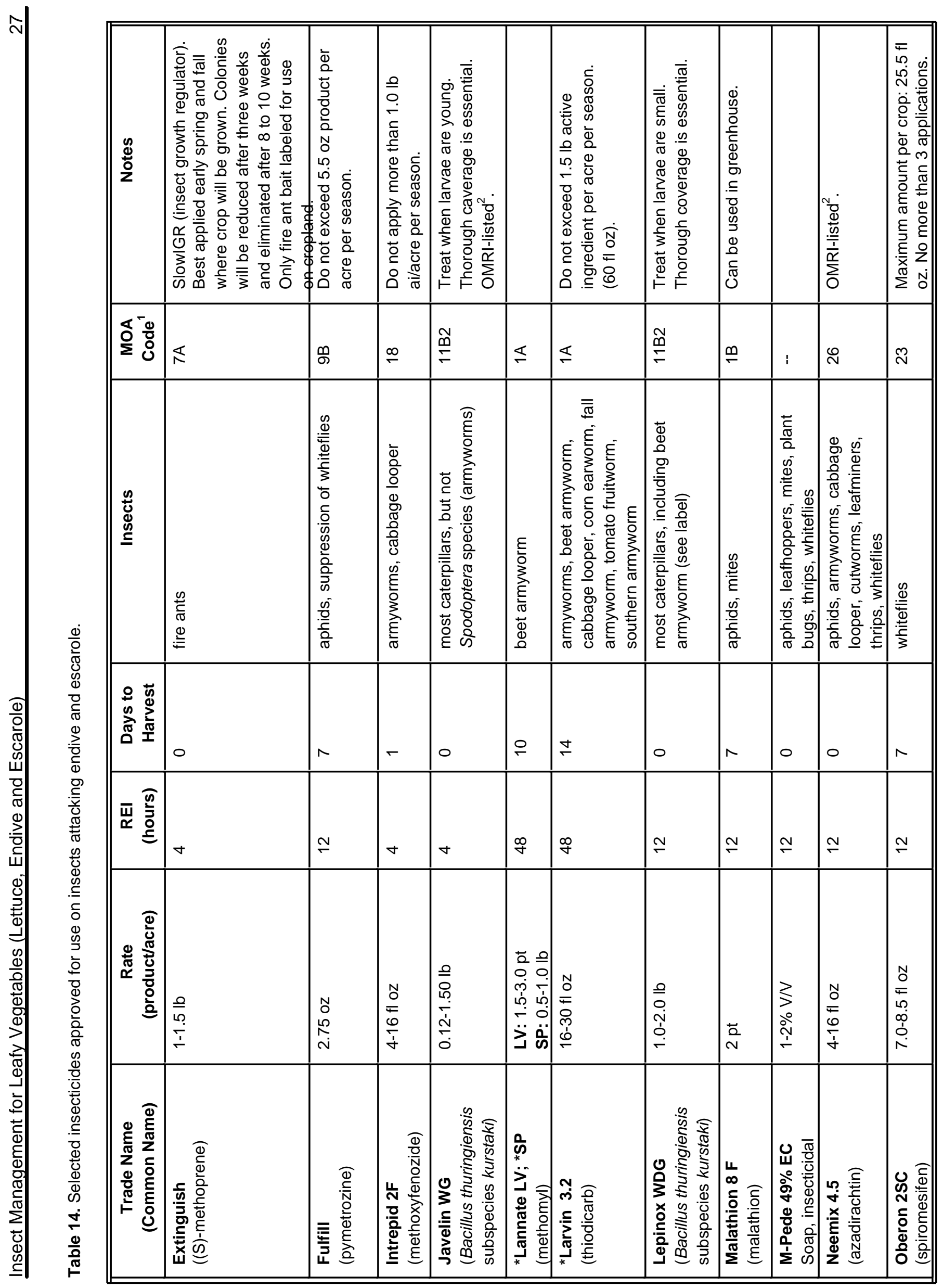




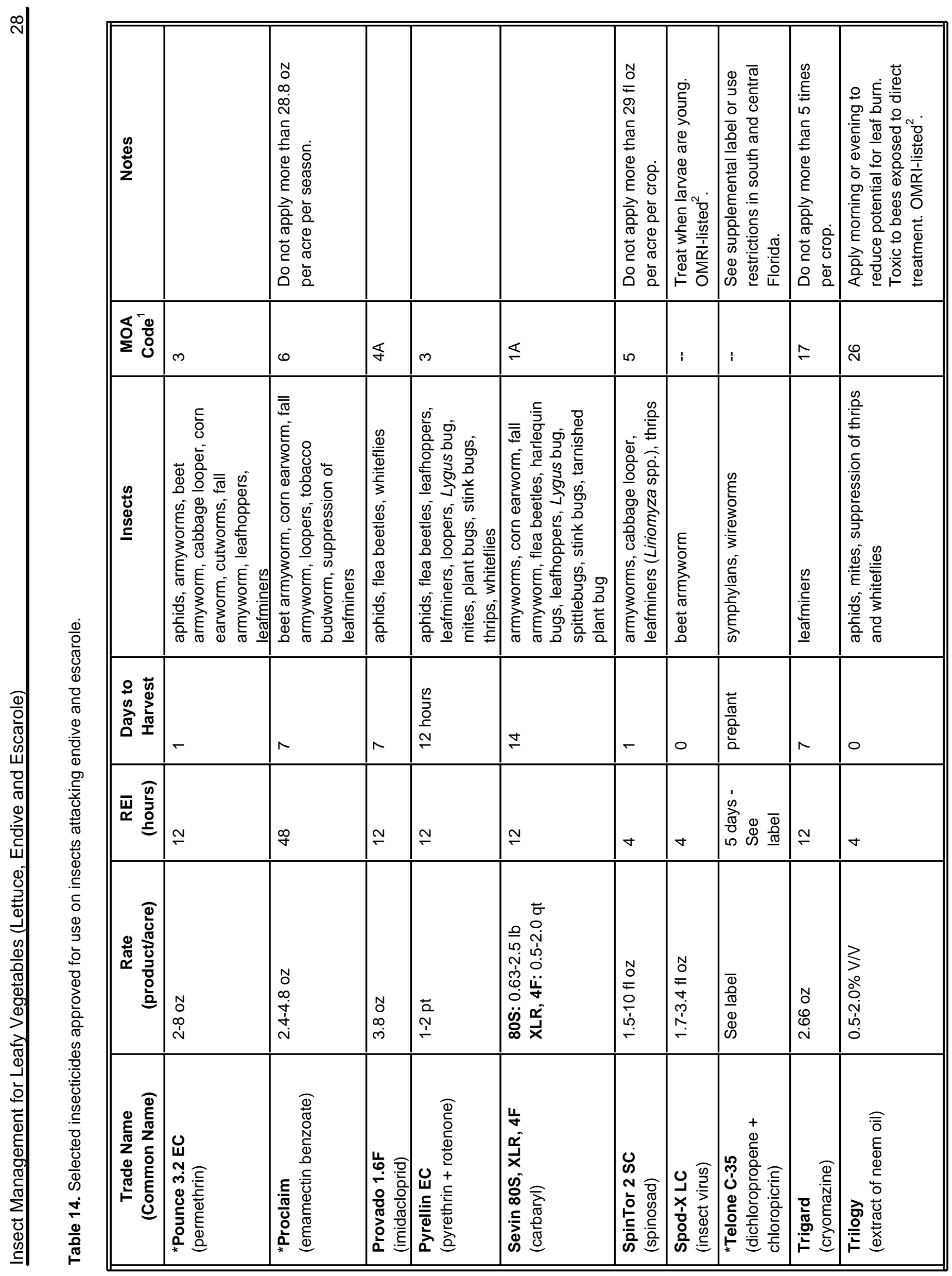




\begin{tabular}{|c|c|c|c|c|}
\hline \multirow{7}{*}{ 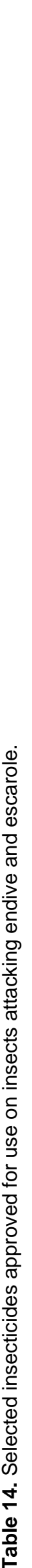 } & $\frac{\mathscr{Q}}{\stackrel{0}{0}}$ & 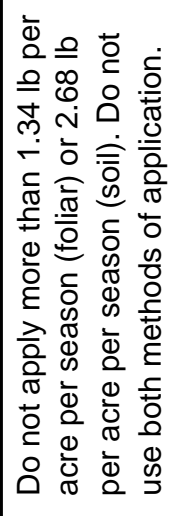 & 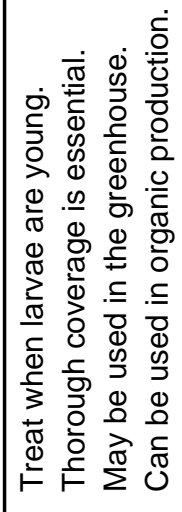 & 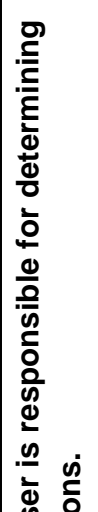 \\
\hline & 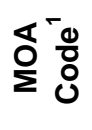 & $\varangle$ & $\stackrel{\bar{m}}{\frac{\Phi}{\tau}}$ & 点 \\
\hline & 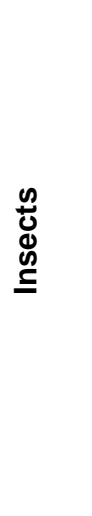 & 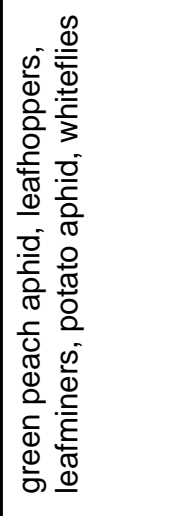 & 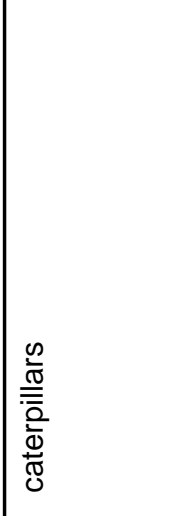 & 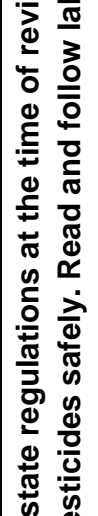 \\
\hline & 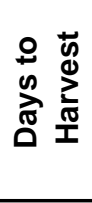 & 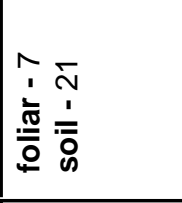 & 0 & 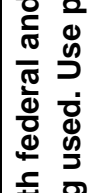 \\
\hline & 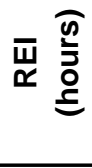 & $\cong$ & $\nabla$ & 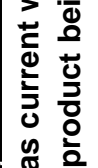 \\
\hline & 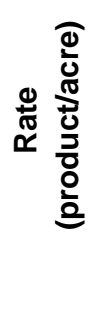 & 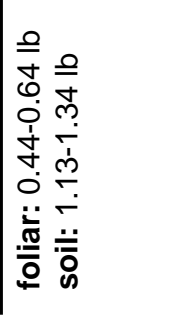 & 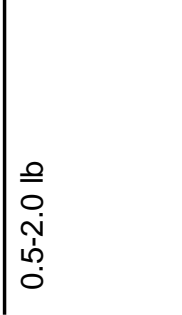 & 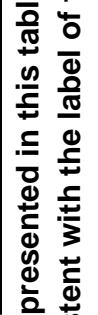 \\
\hline & 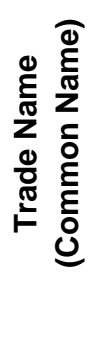 & 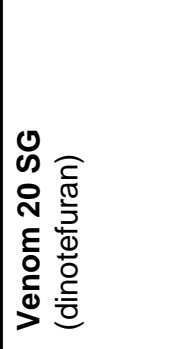 & 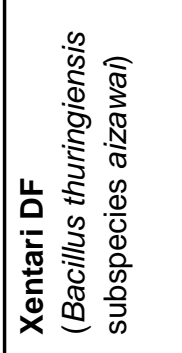 & 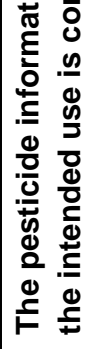 \\
\hline
\end{tabular}




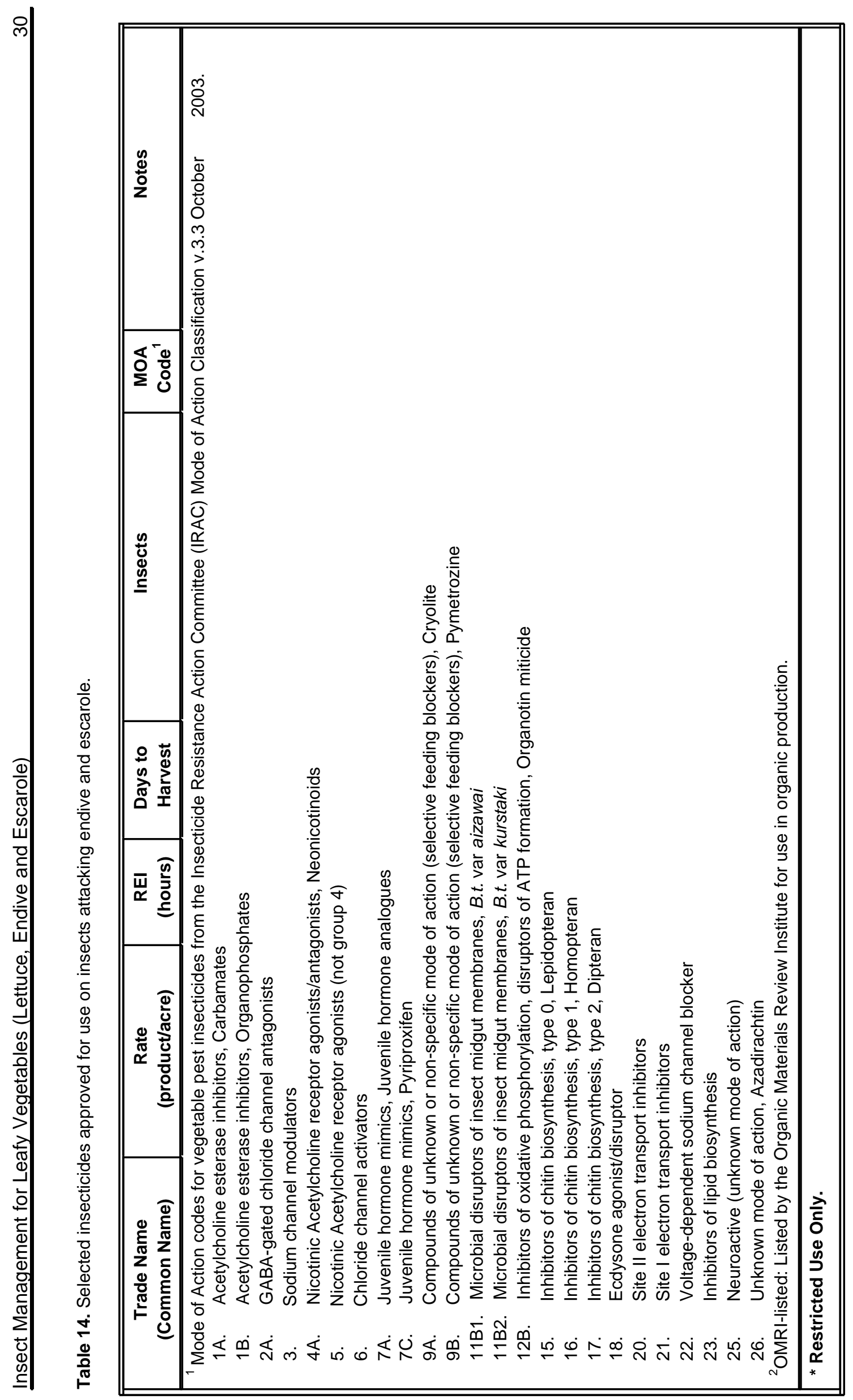

